\title{
Potential Benefits of Probiotics and Prebiotics for Coronary Heart Disease and Stroke
}

\author{
Haicui Wu ${ }^{1,2}$ and Jiachi Chiou $1,2, *$ (D) \\ 1 Department of Applied Biology and Chemical Technology, The Hong Kong Polytechnic University, \\ Hung Hom, Kowloon, Hong Kong, China; wu.hc.wu@connect.polyu.hk \\ 2 Research Institute for Future Food, The Hong Kong Polytechnic University, Hung Hom, Kowloon, \\ Hong Kong, China \\ * Correspondence: jiachi.amber.chiou@polyu.edu.hk; Tel.: +852-3400-8664
}

Citation: $\mathrm{Wu}, \mathrm{H}$.; Chiou, J. Potential Benefits of Probiotics and Prebiotics for Coronary Heart Disease and Stroke. Nutrients 2021, 13, 2878. https://doi.org/10.3390/nu13082878

Academic Editors:

Miguel Romero-Pérez, Juan

Manuel Duarte Pérez and Manuel Sánchez Santos

Received: 30 June 2021

Accepted: 19 August 2021

Published: 21 August 2021

Publisher's Note: MDPI stays neutral with regard to jurisdictional claims in published maps and institutional affiliations.

Copyright: (c) 2021 by the authors. Licensee MDPI, Basel, Switzerland. This article is an open access article distributed under the terms and conditions of the Creative Commons Attribution (CC BY) license (https:/ / creativecommons.org/licenses/by/ $4.0 /)$.

\begin{abstract}
Among cardiovascular diseases (CVDs), a major cause of morbidity and mortality worldwide, coronary heart disease and stroke are the most well-known and extensively studied. The onset and progression of CVD is associated with multiple risk factors, among which, gut microbiota has received much attention in the past two decades. Gut microbiota, the microbial community colonizing in the gut, plays a prominent role in human health. In particular, gut dysbiosis is directly related to many acute or chronic dysfunctions of the cardiovascular system (CVS) in the host. Earlier studies have demonstrated that the pathogenesis of CVD is strongly linked to intestinal microbiota imbalance and inflammatory responses. Probiotics and prebiotics conferring various health benefits on the host are emerging as promising therapeutic interventions for many diseases. These two types of food supplements have the potential to alleviate the risks of CVD through improving the levels of several cardiovascular markers, such as total and low-density lipoprotein (LDL) cholesterol, high sensitivity C-reactive protein (hs-CRP), and certain cytokines involved in the inflammatory response. In this review, we focus mainly on the preventive effects of probiotics and prebiotics on CVD via rebalancing the structural and functional changes in gut microbiota and maintaining immune homeostasis.
\end{abstract}

Keywords: CVD; probiotics; prebiotics; gut microbiota; immune homeostasis

\section{Introduction}

In recent decades, CVD has been the principal contributor of early death and disability in low- and middle-income countries [1]. In most developed countries, over half of deaths in the middle-aged population and one-third of deaths in the elderly population are attributed to CVD [2]. CVD is a collective term, referring to a group of abnormalities in the CVS, and includes coronary heart disease (CHD, sometimes called ischemic heart disease or coronary artery disease), cerebrovascular disease, and peripheral vascular disease, which affect the blood supply to the heart, brain, and the peripheral regions of the body [2]. It is reported that half of the deaths from CVD are caused by CHD in the United States [3].

Unhealthy lifestyle, including an unbalanced diet, alcohol consumption, smoking, and physical inactivity, plays a crucial role in the etiology of CVD and is strongly related to CVD risk. The beneficial effects of probiotics and prebiotics on host health have been widely studied. The term probiotics originates from the Greek, meaning "for life". The definition of probiotics established in 2014 by the joint Food and Agriculture Organization of the United Nations (FAO) and the World Health Organization (WHO) and accepted by the International Scientific Association for Probiotics and Prebiotics (ISAPP) is "live strains of strictly selected microorganisms which, when administered in adequate amounts, confer a health benefit on the host" [4]. The definition of "prebiotics" was first proposed by Gibson and Roberfroid in 1995 and further updated in 2004 as "non-digestible food components allowing the specificity of microbial changes in the intestinal tract, thereby 
exhibiting beneficial effects on host's health" $[5,6]$. Currently, the most widely accepted definition of this term is reaffirmed by the International Scientific Association for Probiotics and Prebiotics (ISAPP) as a substrate that is selectively utilized by host microorganisms conferring a health benefit [4]. Probiotics and prebiotics are beneficial for human health and have long been recognized as potential dietary supplements to prevent the development of various bowel diseases, such as diarrhea and inflammatory bowel disease (IBD). In addition to the intestinal tract, where they pass through and may exert direct functions, accumulating evidence suggests that both probiotics and prebiotics could ameliorate metabolic disorders, including obesity, diabetes, and CVD [7-9]. Although functional foods have exhibited cardiovascular protective effects, the roles of probiotic and prebiotic supplements in the prevention and treatment of CVD are often based on brief reports and small-scale clinical studies, and the mechanisms have not been clearly elucidated. They have been indicated to protect against CVD by lowering cholesterol levels, attenuating oxidative stress, balancing functional and structural changes of gut microbiota, and improving immune responses [9-11].

Thanks to the advanced high-throughput techniques to sequence the gut microbiota, the role of gut microbiota in human health and well-being are being widely studied [12]. A growing body of evidence has demonstrated that the alteration of gut microbiota is linked to many diseases, including CVD [13]. The imbalance of intestinal microbiota has been observed in heart failure, thrombosis, atherogenesis, and arterial hypertension [14-17]. Probiotics and prebiotics playing positive roles in altering the microbial and metabolic composition of gut microbiota could be regarded as a potential therapeutic tactic for CVD.

The protective effects of probiotic and prebiotic therapies on CVD could also be explained by modulation of the host immune system. The immunological mechanisms underpinning probiotics and prebiotics involve the alterations of dendritic cells, epithelial cells, T regulatory cells, effector lymphocytes, natural killer T cells, and B cells [18]. Many chronic diseases are accompanied by low-grade inflammation, which is also the case for CVD. The plasma levels of proinflammatory factors IL-1, IL-6, and TNF- $\alpha$, activated by innate and adaptive immune cells, are frequently found in CVDs [19].

This review aims to discuss the roles of probiotics and prebiotics as important dietary components in the development of major CVDs, namely CHD and stroke, via modulating the gut microbiota and immune system, based on available investigations.

\section{CVD: Prevalence, Pathogenesis, and Risk Factors}

Cardiovascular disease refers to any abnormalities involving the heart or blood vessels and includes CHD, stroke, high blood pressure, venous thrombosis, thromboembolic disease, cardiomyopathy, and arrhythmia [2]. The most well-known and extensively studied CVDs are CHD and stroke. As the leading cause of mortality at the global level, CVD contributes to $30 \%$ of all deaths across the world [1]. In addition, a report from World Health Organization (WHO) predicted that 23.6 million people will die due to CVDs, mainly from heart disease and stroke, by 2030. In the United States, approximately $43.9 \%$ of the population will develop CVD by 2030, as reported by the American Heart Association [20].

It has been shown that CVDs can be formed due to lesions on the coronary, cerebral, or peripheral arteries. The common pathophysiology in these diseases includes atherosclerosis, thrombosis, and clotting [21,22]. It is suggested that the initiation and progression of atherosclerosis are regulated by various immune responses [23]. Atherosclerosis is characterized by the presentation and progressive growth of atherosclerotic plaques (mainly lipid) in the walls of arteries. The lipid of those plaques is mainly cholesterol from LDL particles present in circulation. Lipoproteins enter the subendothelial space of arteries and activate endothelial cells. Meanwhile, monocytes in the vascular wall differentiate into macrophages, which engulf lipoproteins and become the so-called foam cells characteristic of atherosclerotic plaque [24]. Thus, atherosclerosis is a lipid-driven, chronic inflammatory disease, which is a principle predisposing factor for heart disease and stroke. The second 
common pathophysiology of CVD is clotting, which is initially produced in an inactive form, a precursor or zymogen, and subsequently depends upon a cascade of proteolytic reactions [2].

Since CVD represents a complex condition and involves various diseases, numerous risk factors have been reported to contribute to the occurrence of CVD. In general, the factors contributing to CVD can be categorized as non-modifiable risk factors and modifiable risk factors [25]. The non-modifiable risk factors are age, gender, and family history (genetics), while the modifiable factors include hypertension, smoking, diabetes mellitus, physical inactivity, obesity, unhealthy diet, cholesterol and lipids, depression and anxiety, and stress. Based on the risk factors for CVD, numerous therapeutic strategies-mainly medications and lifestyle modifications-have been suggested and applied [26-28]. The use of medications to prevent CVD-related diseases has drawbacks, including increased final burden in end organs, worsened compliance rates, and increased rates of side effects due to medication interactions [29]. These disadvantages have driven the development of new treatment options for CVD, highlighting the importance of adopting a healthy lifestyle, including consuming functional foods [30]. The bioactive compounds of functional foods are crucial for the prevention of CVD progression by altering the structure and function of gut microbiota and the associated immune responses [31,32]. Earlier literature has provided ample evidence that functional foods containing probiotics and prebiotics could prevent several cardio-metabolic disorders, including obesity, type I diabetes, and hypertension $[7,8,33]$.

In this review, we combine the protective effect of probiotics and prebiotics on CHD and stroke via alteration of gut microbiota and modulation of host immune responses, providing implications for this complex disease with promising therapeutic strategies.

\section{Gut Microbiota and CVD}

Gut microbiota is a set of microorganisms colonizing in our gut and contains bacteria, archaea, viruses, and unicellular eukaryotes [34]. Bacteria, as part of this microbial community, have been most widely studied, to determine their roles in affecting human health. The number of bacteria cells in the gastrointestinal tract (GIT) is estimated to be approximately $3.8 \times 10^{13}$, similar to that of total human cells in the body. Yet, the total mass of gut microbiota in a healthy individual is only $0.3 \%$ of the total body weight [35]. Intriguingly, there are 9 million unique genes present in the GIT, observed in the metagenomic studies, which is 450 times more than the whole genome in the human body [36,37].

A growing body of evidence indicates that gut microbiota is linked to the development of several cardio-metabolic diseases, such as diabetes mellitus, obesity, hypertension, and CVD [38]. Structural changes in the gut microbiota have been observed in various diseases. For instance, the ratio of Firmicutes and Bacteroidetes (F/B ratio), as well as the evenness, richness, and diversity of gut microbiota, are routinely reported to decrease in the aforementioned disorders [38-41]. Moreover, several unique bacterial species in the GIT have been reported to play crucial roles in human health. Recently, a promising candidate, Akkermansia muciniphila, was proposed to harbor the potential to be the socalled next-generation probiotic, despite not yet being included in the list of conventional probiotics. The relative abundance of $A$. muciniphila is positively associated with healthy status in comparison to patients with obesity and diabetes [42]. On the other hand, some cultivable microbes present in the gut have been long recognized to cause diseases, e.g., the diarrheagenic bacterial pathogens E. coli, Salmonella, Campylobacter, and Shigella species [43]. The microbiota in the gut, also viewed as "bioreactors", could ferment food components and break them into functional metabolites or microbial products, such as short chain fatty acids (SCFAs) and secondary bile acids [44,45]. Thus, the structural and functional changes in gut microbiota play an important role in maintaining host health.

Intestinal microbiota and their metabolites are strongly associated with the progression of CVD [46]. Pathogens including Shigella, Campylobacter, Yersinia, Streptococcus spp., as well as Enterobacteriaceae and Candida, were observed to be abundant in the stool samples 
of patients with CVD [47,48]. In addition, metagenomic and metabolomic analyses of fecal and plasma samples, respectively, in healthy populations and chronic heart failure (CHF) patients showed that the composition and metabolites of gut microbiota were significantly different. In this study, the abundance of Faecalibacterium prausnitzii was lower, while $R u$ minococcus gnavus was higher, in CHF than those in controls. The increase of butyrate and the decrease of trimethylamine N-oxide (TMAO) were also observed in CHF [49]. TMAO, one of the well-studied metabolites formed by gut microbiota, is positively correlated with early atherosclerosis [50]. This metabolite increases atherosclerotic plaque size, triggers prothrombotic platelet function, and promotes arterial thrombus growth. Another investigation suggested that the increased TMAO levels derived from gut microbiota through the metabolism of choline in female C57BL/6 $\mathrm{ApoE}^{-/-}$mice administered a choline diet promoted the formation of atherosclerosis [51]. In addition, the microbial cell wall component of Gram-negative bacteria, lipopolysaccharide (LPS), may compromise cardiovascular function and increase CVD risk. Intake of low-dose LPS in animal models resulted in vascular inflammation and atherosclerosis $[52,53]$. In addition, circulating endotoxemia (LPS) was most notable in those with the highest CVD burden. Resultant endotoxemia is associated with systemic inflammation, markers of malnutrition, cardiac injury, and reduced survival [54]. The primary bile acids are synthesized from cholesterol in the liver and further metabolized by the gut microbiota into secondary bile acids. A high level of secondary bile acids, produced solely by intestinal bacteria, in the enterohepatic circulation of some individuals may be involved in the progression of several diseases, including CVD [55]. Hence, the composition of commensal microbiota and their metabolites act as an emerging risk factor for CVD.

\section{Probiotics and Their Potential Role in CVD}

\subsection{Probiotics}

Probiotics contain a set of beneficial microorganisms. Most of these belong to lactic acid bacteria, such as Lactobacillus, Bifidobacterium, Lactococcus, Streptococcus, and Enterococcus. The yeast genus Saccharomyces is also one of the well-known probiotics [56]. Currently, fermented foods, including yogurt, kefir, sauerkraut, and kimchi, serving as part of the human diet, are the main source of probiotic strains. There are several criteria for evaluating whether probiotics could be used in food in clinical research. These criteria are (1) proper identification, characterization, and maintenance of probiotic strains; (2) keeping the studied probiotics in live condition; and (3) ensuring they are alive at the site of action in the studies. In addition, the number of living microorganisms in foods containing probiotics at the time of human consumption should be above $10^{6}$ cells $/ \mathrm{mL}$ or cells $/ \mathrm{g}$, according to the $\mathrm{WHO}$, and the therapeutic dose in clinical study is $10^{8}-10^{9}$ cells $/ \mathrm{mL}$ or cells/g [57].

Unequivocal evidence demonstrates probiotics provide benefits for human health and play a crucial role in the prevention of various diseases [58]. The intake of probiotics could directly pass to the GIT and has been reported to be effective in the treatment of various types of diarrhea, especially traveler's diarrhea, antibiotic-induced diarrhea, diarrheal diseases in young children caused by rotavirus, and inflammatory bowel disease (IBD), via counteracting the activity of pathogenic intestinal microbes and promoting the proper balance between pathogens and the commensal bacteria necessary for normal functions in the gut [59]. The potential application of probiotics also includes the prevention and treatment of cancer [60], food allergy [61], and atopic dermatitis [62]. The mechanisms of the beneficial effects of probiotics on human health or their preventive abilities against diseases are mainly due to competing with pathogenic microorganisms, antagonizing pathogens, altering gut microbiome, or modulating the immune response in the host [58]. While the ameliorative effects of traditional probiotics have been widely studied, recent studies have unraveled potential next-generation probiotics (NGPs) from gut microbiota [63]. For example, Bacteroides fragilis shows anticancer effects and attenuates inflammation [64], 
Faecalibacterium prausnitzii protects mice against intestinal diseases [65], and Prevotella copri and Christensenella minuta play a role in controlling insulin resistance [66].

\subsection{Beneficial Effects of Probiotics on CVD}

CVD is a term representing a group of diseases and has a complex etiology for pathogenesis. Here, we discuss and summarize the role of probiotics in the well-known CVDs, namely CHD and stroke. We searched from the database "PubMed" using keywords "probiotics and coronary heart disease or coronary artery disease" from 2000 to 2021. A total of 83 relevant articles were present, but only 12 studies were selected according to title and abstract. Those studies showed that probiotic strains exhibited beneficial effects on CHD (Table 1). Three of these investigations, reported by Raygan et al., indicate that the supplementation of probiotics and co-supplementation with probiotics and vitamin $\mathrm{D}$ or selenium for diabetic patients with CHD could significantly improve the biomarkers of mental health and metabolic profiles, such as hs-CRP, nitric oxide (NO), LDL or total cholesterol, and the parameters involved in inflammation and oxidative stress [67-69]. Another two articles report that supplementation with synbiotics, containing probiotic strains and prebiotic "inulin", in patients with CHD displayed improvement in the levels of several biomarkers, including serum hs-CRP, cholesterol, plasma NO, and malondialdehyde (MDA) [70,71]. The other three reported articles are linked to coronary artery disease (CAD). L. plantarum 299v (Lp299v) supplementation ameliorated vascular endothelial function and attenuated system inflammation in men with CAD [72]. The intake of Lactobacillus rhamnosus GG (LGG) also exhibited beneficial effects in reducing metabolic endotoxemia and mega inflammation in participants with CAD [73]. Another study conducted by the same group found that co-supplementation of probiotics and inulin in CAD subjects for eight weeks had beneficial effects on depression, anxiety, and inflammatory biomarkers [74]. On the other hand, the beneficial roles of probiotics on stroke have been researched, and four articles were found (Table 1). However, all the benefits of probiotic strains on stroke were observed in rodent models. In mice, 2 weeks of treatments with Clostridium butyricum and a probiotic mixture including Bifidobacterium breve, Lactobacillus casei, L. bulgaricus (L. delbrueckii subsp. bulgaricus), and L. acidophilus improved ischemia via the mechanisms involved in anti-oxidation and anti-inflammation and ameliorated neurological deficits $[75,76]$. The intake of probiotic Bacillus licheniformis CMCC 63516 showed preventive effects on heat stroke in rats by sustaining intestinal barrier function, such as increasing tight junctions and decreasing intestinal injury and modulating gut microbiota, e.g., increasing the ratio of Lactobacillus and Lactococcus in the gut microbiota [77]. Moreover, the protective effect of Lactobacillus amylovorus DSM 16698T (ILA) on cerebral ischemia reperfusion injury in rats was observed through attenuating cerebral infarction volume and neural cell apoptosis, decreasing the levels of MDA and TLR-4, and increasing superoxide dismutase (SOD) activity [78]. The protective roles of probiotics as potential dietary supplementation against other CVDs have also been investigated, though those studies are not presented in this review.

Table 1. Beneficial effects of probiotics on CHD and stroke.

\begin{tabular}{|c|c|c|c|c|c|c|c|}
\hline Disease & Product & $\begin{array}{l}\text { Probiotic } \\
\text { Strains }\end{array}$ & Subject & Dose & Duration & Outcomes & Reference \\
\hline $\begin{array}{c}\text { Type } 2 \\
\text { diabetic } \\
\text { patients with } \\
\text { CHD }\end{array}$ & Probiotic & $\begin{array}{l}\text { B. bifidum, } \\
\text { L. casei, } \\
\text { L. } \\
\text { acidophilus }\end{array}$ & Human & $\begin{array}{c}2 \times 10^{9} \\
\text { CFU/day }\end{array}$ & 12 weeks & $\begin{array}{c}\text { Fasting plasma glucose, } \\
\text { insulin, insulin resistane } \\
\text { and total/HDL cholesterol } \\
\text { ratio } \downarrow \\
\text { Insulin sensitivity and } \\
\text { HDL cholesterol levels } \uparrow, \\
\text { hs-CRP } \downarrow \\
\text { Antioxidant capacity and } \\
\text { total glutathione levels } \uparrow\end{array}$ & [67] \\
\hline
\end{tabular}


Table 1. Cont.

\begin{tabular}{|c|c|c|c|c|c|c|c|}
\hline Disease & Product & $\begin{array}{l}\text { Probiotic } \\
\text { Strains }\end{array}$ & Subject & Dose & Duration & Outcomes & Reference \\
\hline $\begin{array}{l}\text { Diabetic } \\
\text { people with } \\
\text { CHD }\end{array}$ & $\begin{array}{l}\text { Vitamin D } \\
\text { and } \\
\text { probiotics }\end{array}$ & $\begin{array}{c}\text { L. } \\
\text { zisttakhmir }\end{array}$ & Human & $\begin{array}{l}8 \times 10^{9} \\
\mathrm{CFU} / \mathrm{g}\end{array}$ & 12 weeks & $\begin{array}{c}\text { Serum insulin levels } \downarrow \\
\text { Serum } 25 \text {-OH-vitamin D } \uparrow \\
\text { Serum HDL cholesterol } \\
\text { levels } \uparrow \\
\text { Serum hs-CRP, plasma } \\
\text { NO, and plasma TCA } \uparrow\end{array}$ & [68] \\
\hline $\begin{array}{c}\text { Type } 2 \\
\text { diabetic } \\
\text { patients with } \\
\text { CHD }\end{array}$ & $\begin{array}{l}\text { Probiotic } \\
\text { and } \\
\text { selenium }\end{array}$ & $\begin{array}{l}\text { L. } \\
\text { acidophilus, } \\
\text { L. reuteri, } \\
\text { L.fermentum, } \\
\text { B. bifidum }\end{array}$ & Human & $\begin{array}{l}2 \times 10^{9} \\
\mathrm{CFU} / \mathrm{g}\end{array}$ & 12 weeks & $\begin{array}{c}\text { Fasting plasma glucose, } \\
\text { serum insulin levels, } \\
\text { insulin resistance } \downarrow \\
\text { Triglycerides, VLDL and } \\
\text { total cholesterol, and hs } \\
\text { CRP } \downarrow \\
\text { NO } \uparrow\end{array}$ & [69] \\
\hline $\begin{array}{c}\text { Type } 2 \\
\text { diabetic } \\
\text { patients with } \\
\text { CHD }\end{array}$ & Synbiotic & $\begin{array}{l}\text { L. } \\
\text { acidophilus, } \\
\text { L. casei, } \\
\text { B. bifidum }\end{array}$ & Human & $\begin{array}{l}2 \times 10^{9} \\
\mathrm{CFU} / \mathrm{g}\end{array}$ & 12 weeks & $\begin{array}{c}\text { Fasting plasma glucose, } \\
\text { serum insulin } \\
\text { concentrations } \downarrow \\
\text { HLDL-cholesterol levels } \uparrow\end{array}$ & [70] \\
\hline $\begin{array}{l}\text { Overweight, } \\
\text { diabetes, and } \\
\text { CHD }\end{array}$ & Synbiotic & $\begin{array}{c}\text { L. } \\
\text { acidophilus } \\
\text { strain T16 } \\
\text { (IBRC- } \\
\text { M10785), L. } \\
\text { casei strain } \\
\text { T2 (IBRC- } \\
\text { M10783) B. } \\
\text { bifidum } \\
\text { strain T1 } \\
\text { (IBRC- } \\
\text { M10771) }\end{array}$ & Human & $\begin{array}{l}2 \times 10^{9} \\
\mathrm{CFU} / \mathrm{g}\end{array}$ & 12 weeks & $\begin{array}{c}\text { Serum hs-CRP and } \\
\text { plasma MDA } \downarrow \\
\text { Plasma NO } \uparrow\end{array}$ & [71] \\
\hline $\begin{array}{l}\text { Men with } \\
\text { stable CAD }\end{array}$ & Probiotic & $\begin{array}{c}L . \\
\text { plantarum } \\
299 \mathrm{v} \\
(\text { Lp299v) }\end{array}$ & Human & $\begin{array}{l}2 \times 10^{10} \\
\mathrm{CFU} / \mathrm{d}\end{array}$ & 6 weeks & $\begin{array}{c}\mathrm{NO} \uparrow \\
\text { IL-8, IL-12, and leptin } \\
\text { levels } \downarrow\end{array}$ & [72] \\
\hline CAD patients & Probiotic & $\begin{array}{c}\text { L. } \\
\text { rhamnosus } \\
\text { GG (LGG) }\end{array}$ & Human & $\begin{array}{c}1.6 \times 10^{9} \\
\mathrm{CFU} / \mathrm{d}\end{array}$ & 12 weeks & $\begin{array}{l}\text { IL1-Beta } \downarrow \\
\text { LPS } \downarrow\end{array}$ & [73] \\
\hline CAD patients & Synbiotic & $\begin{array}{c}\text { L. } \\
\text { rhamnosus } \\
\text { GG (LGG) }\end{array}$ & Human & $\begin{array}{c}1.9 \times 10^{9} \\
\mathrm{CFU} / \mathrm{d}\end{array}$ & 8 weeks & $\begin{array}{c}\text { hs-CRP } \downarrow \\
\text { LPS } \downarrow \\
\text { TNF- } \alpha \downarrow\end{array}$ & [74] \\
\hline $\begin{array}{l}\text { I schemic } \\
\text { stroke }\end{array}$ & Probiotics & $\begin{array}{c}\text { C. } \\
\text { butyricum }\end{array}$ & $\begin{array}{l}\text { Male ICR } \\
\text { mice }\end{array}$ & $\begin{array}{l}\text { No } \\
\text { mention }\end{array}$ & 2 weeks & $\begin{array}{c}\text { MDA and TNF- } \alpha \downarrow \\
\text { SOD activity } \uparrow \\
\text { Caspase-3, Bax and } \\
\text { Bcl/Bax } \downarrow \\
\text { Butyrate contents } \uparrow\end{array}$ & [75] \\
\hline $\begin{array}{l}\text { Focal } \\
\text { cerebral } \\
\text { ischemia in } \\
\text { mice }\end{array}$ & Probiotics & $\begin{array}{c}\text { B.breve, } \\
\text { L.casei, } \\
\text { L.bulgaricus } \\
\text { (L.delbrueckii } \\
\text { subsp. } \\
\text { bulgaricus), } \\
\text { L. } \\
\text { acidophilus }\end{array}$ & $\begin{array}{c}\text { Male } \\
\text { BLC57 mice }\end{array}$ & $\begin{array}{c}10^{7} \\
\mathrm{CFU} / \mathrm{mL}\end{array}$ & 14 days & $\begin{array}{c}\text { Infarct size } \downarrow \\
\text { MDA and TNF- } \alpha \downarrow\end{array}$ & [76] \\
\hline
\end{tabular}


Table 1. Cont.

\begin{tabular}{|c|c|c|c|c|c|c|c|}
\hline Disease & Product & $\begin{array}{l}\text { Probiotic } \\
\text { Strains }\end{array}$ & Subject & Dose & Duration & Outcomes & Reference \\
\hline $\begin{array}{c}\text { Heat stroke } \\
\text { in rats }\end{array}$ & Probiotics & $\begin{array}{l}\text { Bacillus } \\
\text { licheni- } \\
\text { formis } \\
\text { strain (BL, } \\
\text { CMCC } \\
63516)\end{array}$ & $\begin{array}{c}\text { Male } \\
\text { Sprague- } \\
\text { Dawley } \\
\text { (SD) rats }\end{array}$ & $\begin{array}{c}1 \times 10^{8} \\
\mathrm{CFU} / \mathrm{mL}\end{array}$ & 7 days & $\begin{array}{c}\text { Hyperthermia, } \\
\text { HS-induced death, } \\
\text { multiple-organ injury, } \\
\text { levels of serum } \\
\text { inflammatory cytokines, } \\
\text { and intestinal injury } \downarrow \\
\text { tight junctions } \uparrow \\
\text { Ratios of Lactobacillus and } \\
\text { Lactococcus in gut } \\
\text { microbiota } \uparrow\end{array}$ & [77] \\
\hline $\begin{array}{l}\text { Cerebral } \\
\text { ischemia } \\
\text { reperfusion } \\
\text { injury in rats }\end{array}$ & Probiotics & $\begin{array}{c}\text { Lactobacillus } \\
\text { ILA } \\
\text { amylovorus } \\
\text { DSM } \\
\text { 16698T } \\
\text { (ILA) }\end{array}$ & Male SD rat & $\begin{array}{c}10^{6}, 10^{7} \\
\text { and } 10^{8} \\
\text { CFU } / \mathrm{mL}\end{array}$ & $2 \mathrm{~h}$ & $\begin{array}{c}\text { Cerebral infarction } \\
\text { volume and neural cell } \\
\text { apoptosis } \downarrow \\
\text { MDA and TLR-4 } \downarrow \\
\text { SOD activity } \uparrow \\
\text { IkB and A20 } \uparrow\end{array}$ & [78] \\
\hline
\end{tabular}

hs-CRP, high sensitivity C-reactive protein; NO, nitric oxide; TAC, total antioxidant capacity; MDA, malondialdehyde; TLR-4, Toll-like receptor-4;SOD, superoxide dismutase; $\downarrow$, the levels, size or abundance decreased; $\uparrow$, the levels, size or abundance increased.

\subsection{Underlying Mechanisms of Probiotics on CVD}

Sánchez et al. proposed four different mechanisms contributing to the beneficial effects of probiotics on human health: (1) amelioration of the epithelial barrier function; (2) competing against pathogens with nutrients and adhesion sites; (3) effect on other tissues by the immune system and neurotransmitter production; and (4) immunomodulation [79]. The underlying mechanisms of probiotics on CVD are relatively complicated and are yet to be elucidated. Here, we discuss the preventive effects of probiotics on CVD via restoration of gut microbiota dysbiosis and anti-inflammatory responses, though the mechanisms of the beneficial effects of probiotics on CVD likely include reducing oxidative stress, lowering hypercholesterolemia, and lowering high blood pressure [9].

(1) From the view of gut microbiota

The changes in gut microbiota, which is associated with the mediation of cholesterol metabolism, uric acid metabolism, oxidative stress, and inflammatory reactions through various metabolites, could be involved in the development of atherosclerosis, the major risk factor for CHD and stroke [80-83]. A study conducted by Karlsson et al. using a whole-genome sequencing approach suggested that there is a possible link between gut microbiota changes and atherosclerotic heart disease [84]. The abundance of Collinsella was higher, while that of Rothia and Eubacterium spp. was lower, in these patients than in their counterparts in healthy controls. Moreover, the F/B ratio significantly decreased in people with CHD conditions. Later, the proportion of Lactobacilli increased, while Bacteroidetes including Bifidobacterium and Prevotella decreased notably, in patients with CHD compared to healthy volunteers, as reported by Emoto et al. in 2016 and 2017 [85,86]. In several animal-based studies, stroke-induced shifts in the structure of gut microbiota included an increased abundance of Clostridial and A. muciniphila [87]. In addition, the alteration of intestinal microbiota, such as reduced species diversity and overgrowth of Bacteroidetes, was observed in another animal stroke model, the mice middle cerebral artery occlusion model [88]. In patients with ischemic stroke, a reduction in the diversity and increased abundance of Bacteroidetes phylum in the gut microbiota was also found [89].

Current therapies targeting the dyslipidemia associated with atherosclerosis have various side effects. In comparison to pharmaceutical agents, nutraceuticals generated from the food after fermentation by probiotic bacteria have evoked greater interest in atherosclerosis prevention [90]. Supplementation of probiotic L. mucosae A1 exhibited 
effectiveness in the treatment of hyperlipidemia and atherosclerosis and improved gut microbiota dysbiosis, including increased richness and diversity in ApoE ${ }^{-/-}$mice on a Western diet [91]. The anti-atherosclerotic effects of L. plantarum ATCC 14917 were also observed in ApoE ${ }^{-/-}$mice via modulation of proinflammatory cytokines TNF $\alpha$ and IL1- $\beta$, oxidative stress, and gut microbiota [92]. Administration of this probiotic strain increased the proportion of Bacteroidetes, whereas it attenuated the abundance of Firmicutes, Verrucomicrobia, and Proteobacteria. At the family level, Bacteroidaceae was significantly increased, whereas other major families were decreased by this treatment. Moreover, the exopolysaccharide-producing probiotic Lactobacilli mucosae DPC 6426 ameliorated atherosclerosis by reducing serum cholesterol and altering the relative abundance of enteric microbiota, including greater prevalence of Porphyromonadaceae and Prevotellaceae and lower abundance of Clostridiaceae, Peptococcaceae, and Staphylococcaceae in the DPC 6426 group compared with the placebo group [93]. Another study indicated that the $\mathrm{ApoE}^{-/ \text {- }}$ mice supplemented with the probiotic mixture VSL\#3 (a mixture of $S$. thermophilus, B. breve, B. bacterium longum, B. infantis, L. acidophilus, L. plantarum, L. paracasei, and L. delbrueckii subsp. bulgarius) exhibited different intestinal microbiota composition from that of the control groups [94].

Apart from the structural changes in enteric microbiota, several gut-derived metabolites, especially TMAO, are strongly correlated with CHD risk $[95,96]$. Trimethylamine (TMA) is formed from choline, carnitine, and phosphatidylcholine in foods via the intestinal microbial enzyme complex and the carnitine Rieske-type oxygenase/reductase system in the GIT [97,98]. After this compound is formed, it enters the portal vein circulation and is metabolized by the liver enzyme, flavin-containing monooxygenase, to further become TMAO. Probiotics play a potential role in preventing atherosclerosis through the amelioration of TMAO [99]. The development of TMAO-induced atherosclerosis was considerably blocked by L. plantarum ZDY04 in $\mathrm{ApoE}^{-/-}$mice treated with $1.3 \%$ choline as compared with the control group [100]. Moreover, microbiota metabolic changes could be observed with the introduction of probiotics. Administration of fermented milk containing B. animalis subsp. lactis lowered the proportion of several harmful bacteria and modulated the production of SCFAs in the colon [101]. CVDs, such as dyslipidemia and diabetes, could be caused by disorders in the metabolism of bile acid. Lactobacilli play an important role in BA biotransformation by promoting the activity of microbial bile salt hydrolase (BSH), regenerating primary free bile acids, and facilitating the microbial formation of secondary BAs as well as a range of intermediates [55,102]. Therapeutic manipulation of microbiota using different antimicrobial strategies may be a useful approach for the management of cardiovascular-related diseases. Lactobacilli or other lactic acid bacteria are excellent antimicrobial producers and might improve CVD by promoting the growth of beneficial bacteria and inhibiting the production of LPS by Gram-negative bacteria in the GIT.

Although many studies have suggested that probiotics showed preventive effects on CVD, particularly on the development of atherosclerosis, through modulation of gut microbiota, the underlying mechanisms are not clearly elucidated. Here we propose that treatments with different probiotic strains on CVD patients or animals may rebalance bacteria composition and their metabolites in the gut by directly interacting with other beneficial bacteria and competing against harmful microorganisms, or indirectly helping/inhibiting the production of gut-derived metabolites, thereby affecting the downstream inflammatory responses or gene expressions in end-organs of the host (Figure 1). 


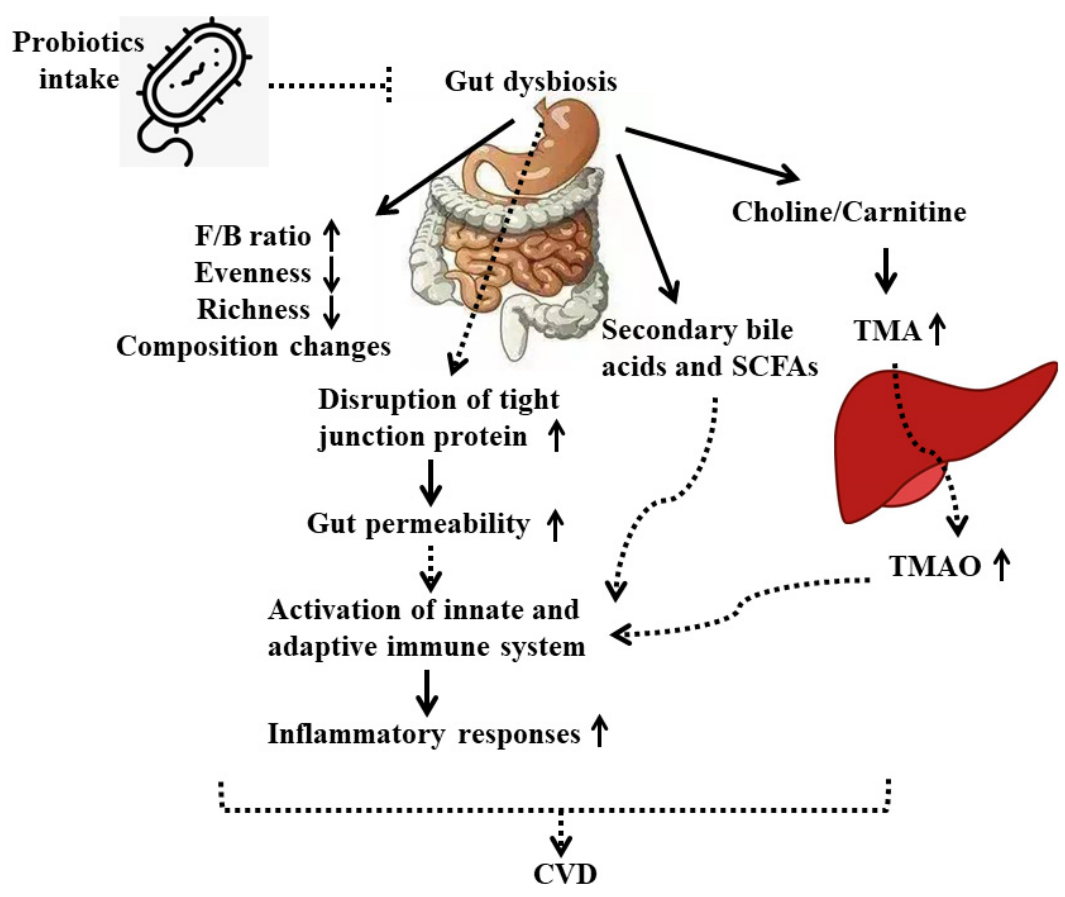

Figure 1. Mechanisms of the beneficial role of probiotics on CVD. Solid line represents direct outcome. Dashed line represents indirect outcome. F/B ratio, Firmicutes to Bacteroidetes ratio; TMA, trimethylamine; TMAO, trimethylamine $\mathrm{N}$-oxide.

(2) From the view of inflammatory response

Many chronic diseases, including CVD, are involved in low-grade inflammation. Frequently, the plasma levels of the main proinflammatory mediators, TNF- $\alpha$, IL-1, and IL-6, are higher in cardiovascular disorders as compared with healthy conditions. The inflammatory biomarkers of CHD include IL-6, C-reactive protein (CRP), complement system, cluster of differentiation 40 (CD40), and myeloperoxidase (MPO) [103]. The abovementioned research regarding the role of probiotics in CHD revealed that administration of pure probiotic strains or the co-supplementation of probiotics with other products attenuated levels of hs-CPR and other inflammatory factors [67-71]. In addition, the anti-inflammatory effects of probiotics on stroke by decreasing the expression of tight junction proteins and inflammatory cytokines such as TNF- $\alpha$ were observed [76-78]. Although these studies demonstrated that the introduction of probiotics is associated with anti-inflammatory effects on CHD and stroke, the mechanism of this action is yet to be investigated.

The consumption of probiotics exhibited beneficial effects on the host through stimulating both the innate and adaptive immune system [104]. The ability of adhesion to intestinal epithelial cells (IECs) is one of the criteria to evaluate probiotics. L. casei CRL 431 and L. paracasei CNCM I-1518 adhere to IECs through the Toll-like receptors (TLRs) and modulate immune response, such as increasing the production of IL-6 and macrophage chemoattractant protein 1 (MCP1) [105]. The intestinal barrier could also be strengthened by probiotics via multiplying the number of Goblet cells, which results in the reinforcement of the mucus layer [106]. Some probiotic strains have been reported to increase the expression of mucin-related proteins, such as MUC2, MUC3, and MUC5AC, in HT29 cells [107]. Oral administration of probiotics also increases the number of Paneth cells and reinforces the intestinal barrier integrity through increased gene expression of tight junction signaling [108-110]. These modulations were involved in anti-inflammatory responses of probiotics. The intake of probiotic strains, such as L. plantarum $299 \mathrm{v}$ and L. rhamnosus GG, could improve CVD via alleviating inflammatory responses, which include decreased IL-8, IL-12, IL-1 $\beta$, and TNF- $\alpha$ in patients [72-74]. In addition, it has been reported that the induction of probiotics C. butyricum, B. breve, L. casei, L. bulgaricus, L. acidophilus, and 
Bacillus licheniformis showed preventive effects on stoke along with reduced levels of inflammatory cytokines in both mice and rats [75-78]. In addition, probiotics could alter specific commensal bacteria of the gut microbiota, such as Prevotella and Oscillibacter, which have been shown to produce anti-inflammatory metabolites and thus decrease Th17 polarization and promote the differentiation of anti-inflammatory $\mathrm{T}_{\text {reg }} /$ Type 1 regulatory $\mathrm{T}(\operatorname{Tr} 1)$ cells in the gut [111].

Approximate $50 \%$ of stroke patients are associated with gastrointestinal complications, which include gut dysmotility, leaky gut, dysbiotic gut microbiotia, and even gut-origin sepsis; these patients have poor stroke outcomes [112]. The underlying mechanisms remain understudied. One possible explanation is the bidirectional communication between the gut and the nervous system: The so-called gut-brain axis. Sympathetic nervous system (SNS) activation is associated with inflammation-induced vascular endothelial dysfunction and cardiometabolic disease [113]. Since some gut bacteria, such as Bifidobacterium and Lactobacillus genera, could produce neurotransmitters, including $\gamma$-aminobutyric acid (GABA), serotonin, dopamine, and norepinephrine, supplementation of probiotics could cause compositional changes of gut microbiota so as to alter the types and concentrations of neurotransmitters, in turn influencing the SNS and subsequent cardiometabolic activities [114,115].

The potential mechanisms of probiotics' beneficial effects on CVDs from the approach of immune responses are shown in Figure 1. Probiotic bacteria interact with IECs or immune cells through TLRs to (1) stimulate mucin production, (2) increase the expression of tight junction proteins, and (3) increase the number of Goblet and Paneth cells, which collectively enhance the intestinal barrier and result in activation of innate and adapted immune response, including production of various cytokines, chemokines, and anti-inflammatory metabolites (Figure 1).

\section{Prebiotics and Their Potential Role in CVD}

\subsection{Prebiotics}

There are several selection criteria for prebiotics, which are (1) resistance to digestion in the upper sections of the alimentary tract, (2) selective fermentation by potentially beneficial microbiota in the colon, (3) beneficial effect on host health, (4) selective stimulation of growth of probiotics, and (5) stability in various food/feed processing conditions [116].

Based on the definition and criteria proposed, a set of potential prebiotics has been recognized over the past decades. Those prebiotics, according to the number of monomers bound together, are sorted into disaccharides, oligosaccharides, and polysaccharides [117]. Research has demonstrated that oligosaccharides, especially fructans (fructooligosaccharides (FOS) and inulin) and galactans (galactooligosaccharides (GOS)), are the wellknown prebiotics, as evidenced by in vitro and in vivo studies. Dietary fiber is also nonfermentable by human digestive enzymes and is sometimes used interchangeably with prebiotics. Dietary fiber is fermentable by the majority of colonic bacteria, which are not well-defined or fermented at all, whereas prebiotics could be used by the strictly defined microorganisms in the colon [118]. Numerous health benefits have been found as a result of the supplementation of prebiotics in the diet. Some investigations have suggested that people consuming high amounts of fiber or other types of prebiotics exhibited considerably lower risk of diabetes, reduced body weight, and decreased colorectal cancer prevalence [119-121].

\subsection{Beneficial Effects of Prebiotics on CVD}

The consumption of prebiotics protects the host against CVD. Using keywords ("prebiotics" or "inulin" or "fructans" or "galactans") and ("cardiovascular diseases" or "coronary heart disease" or "stroke") in PubMed from 2000-2021, we found 167 relevant results, but only 11 articles discussing the roles of prebiotics on CVD after screening title and abstract (Table 2). Among these, most studied the beneficial effects of inulin or the prebiotics containing inulin on various CVDs, including CHD or diabetes associated with CHD, 
coronary artery disease, chronic kidney disease, atherosclerosis, and hypercholesterolemia, in both human patients and animal models [70,71,74,122-124]. Supplementation with inulin (or co-supplementation with inulin and other components) reduced the levels of cholesterol, including total and LDL cholesterol, CRP, and several inflammatory cytokines, and improved anti-oxidative parameters and gut microbiota dysbiosis. Nevertheless, in contrast to previous results, which showed that inulin supplementation is effective at lowering inflammation and plasma lipid levels, one article indicated that inulin aggravated the accelerated atherosclerosis development driven by increased plasma cholesterol in hypercholesterolemic APOE*3-Leiden mice [125]. In addition to inulin, the beneficial roles of other prebiotics or prebiotic complexes in CVD were also reported. The administration of a prebiotic complex based on fermented wheat bran was observed to correct intestinal dysbiosis and endotoxemia in female rats with modeled heart failure [126]. The beneficial effects of dietary supplementation with soluble fiber (Minolest) on the lipid profile in subjects with mild hypercholesterolemia and a low risk of coronary artery disease were determined [127]. Another study found that larch arabinogalactan, an active component of pectin, attenuated myocardial injury by inhibiting apoptotic cascades in a rat model of ischemia-reperfusion [128]. In addition, chitosan oligosaccharides (COS) exhibited protective effects in CHD by ameliorating antioxidant capacities and lipid profiles through promoting the growth of probiotic species in intestinal flora [129]. Altogether, prebiotics could improve symptoms of CVD via several mechanisms involved in inflammation, antioxidant capacity, and rebalancing of the dysbiotic gut microbiota. However, the adverse effects of prebiotics on CVD reported necessitate caution in the application of inulin in humans.

Table 2. Beneficial effects of prebiotics on various CVDs.

\begin{tabular}{|c|c|c|c|c|c|c|c|}
\hline Disease & Product & Prebiotics & Subject & Dose & Duration & Outcomes & Reference \\
\hline $\begin{array}{c}\text { Type } 2 \text { diabetic } \\
\text { patients with CHD }\end{array}$ & Synbiotic & Inulin & Human & $\begin{array}{c}800 \\
\text { mg/day }\end{array}$ & 12 weeks & $\begin{array}{c}\text { Fasting plasma } \\
\text { glucose, serum } \\
\text { insulin } \\
\text { concentrations } \downarrow \\
\text { HLDL cholesterol } \\
\text { levels } \uparrow\end{array}$ & [70] \\
\hline $\begin{array}{c}\text { Overweight, } \\
\text { diabetes, and CHD }\end{array}$ & Synbiotic & Inulin & Human & $\begin{array}{c}800 \\
\text { mg/day }\end{array}$ & 12 weeks & $\begin{array}{c}\text { Serum hs-CRP and } \\
\text { plasma MDA } \downarrow \\
\text { Plasma NO } \uparrow\end{array}$ & [71] \\
\hline CAD patient & Synbiotic & Inulin & Human & $15 \mathrm{~g} /$ day & 2 months & $\begin{array}{c}\text { hs-CRP, LPS, TNF- } \alpha \\
\downarrow\end{array}$ & [74] \\
\hline $\begin{array}{l}\text { Chronic kidney } \\
\text { disease patients }\end{array}$ & Prebiotic & Inulin & Human & 19 g/day & 6 months & $\begin{array}{l}\text { Serum insulin and } \\
\text { fasting glucose } \\
\text { levels, HOMA-IR, } \\
\text { total cholesterol, } \\
\text { Triglycerides, CRP } \\
\text { and homocysteine } \downarrow \\
\text { HDL cholesterol } \uparrow\end{array}$ & [122] \\
\hline $\begin{array}{c}\text { Women with type } 2 \\
\text { diabetes }\end{array}$ & Prebiotic & $\begin{array}{l}\text { Inulin and } \\
\text { oligofructose }\end{array}$ & Human & 10 g/day & 8 weeks & $\begin{array}{c}\text { Total antioxidant } \\
\text { capacity } \uparrow \\
\text { Fasting plasma } \\
\text { glucose, HbA1c, } \\
\text { total cholesterol, } \\
\text { LDL cholesterol, } \\
\text { TC/HDL-c ratio, } \\
\text { LDL-c/HDL-c ratio } \\
\text { and } \\
\text { malondialdehyde } \downarrow\end{array}$ & [123] \\
\hline
\end{tabular}


Table 2. Cont.

\begin{tabular}{|c|c|c|c|c|c|c|c|}
\hline Disease & Product & Prebiotics & Subject & Dose & Duration & Outcomes & Reference \\
\hline $\begin{array}{l}\text { Hypercholesterolemic } \\
\text { adults }\end{array}$ & Prebiotic & $\begin{array}{l}\text { Concentrated } \\
\text { oat } \\
\text { beta-glucan } \\
\text { with inulin } \\
\text { and guar } \\
\text { gum }\end{array}$ & Human & $6 \mathrm{~g} /$ day & 6 weeks & $\begin{array}{c}\text { Total cholesterol and } \\
\text { LDL cholesterol } \downarrow \\
\text { SCFAs } \uparrow\end{array}$ & [124] \\
\hline $\begin{array}{l}\text { Atherosclerosis in } \\
\text { hypercholes- } \\
\text { terolemic } \\
\text { APOE*3-Leiden } \\
\text { mice }\end{array}$ & Prebiotic & Inulin & $\begin{array}{l}\text { Male } \\
\text { APOE*3- } \\
\text { Leiden } \\
\text { (E3L) } \\
\text { mice }\end{array}$ & $10 \%$ of diet & 5 weeks & $\begin{array}{l}\text { Atherosclerosis, } \\
\text { number of } \\
\text { macrophages, } \\
\text { smooth muscle cells, } \\
\text { collagen content, } \\
\text { plasma total } \\
\text { cholesterol levels } \uparrow\end{array}$ & [125] \\
\hline $\begin{array}{l}\text { Female rats with } \\
\text { modeled heart } \\
\text { failure }\end{array}$ & $\begin{array}{l}\text { Prebiotics } \\
\text { complex }\end{array}$ & $\begin{array}{l}\text { Prebiotic } \\
\text { complex } \\
\text { based on } \\
\text { fermented } \\
\text { wheat bran }\end{array}$ & $\begin{array}{l}\text { Female } \\
\text { rat }\end{array}$ & $\begin{array}{c}0.5 \\
\text { g/day/rat }\end{array}$ & 21 days & $\begin{array}{c}\text { Concentrations of } \\
\text { endotoxin, markers } \\
\text { of Lactobacilli, and } \\
\text { opportunistic } \\
\text { microorganisms } \downarrow \\
\text { markers of } \\
\text { Bifidobacteria, } \\
\text { Eubacteria, and } \\
\text { Propionibacteria } \uparrow\end{array}$ & [126] \\
\hline $\begin{array}{l}\text { Subjects with hyper- } \\
\text { cholesterolemia }\end{array}$ & Prebiotic & $\begin{array}{l}\text { Soluble fiber } \\
\text { (minolest) }\end{array}$ & Human & $16.5 \mathrm{~g} /$ day & 3 months & $\begin{array}{l}\text { Total cholesterol and } \\
\text { LDL cholesterol } \downarrow\end{array}$ & [127] \\
\hline $\begin{array}{l}\text { A rat model of } \\
\text { ischemia- } \\
\text { reperfusion }\end{array}$ & Prebiotic & $\begin{array}{l}\text { Polysaccharides } \\
\text { of pectin } \\
\text { (larch } \\
\text { arabinogalac- } \\
\quad \text { tan) }\end{array}$ & $\begin{array}{l}\text { Male SD } \\
\text { rat }\end{array}$ & $\begin{array}{c}50 \\
\mathrm{mg} / \mathrm{kg} / \text { day }\end{array}$ & 3 days & $\begin{array}{c}\text { Gelsolin gene } \\
\text { expression, p38 } \\
\text { phosphorylation, } \\
\text { apoptotic cells, and } \\
\text { hif1- } \alpha \text { gene } \\
\text { expression } \downarrow\end{array}$ & [128] \\
\hline
\end{tabular}

Blood urea nitrogen, serum creatinine, antioxidant levels, SOD and GSH $\uparrow$

ALT and AST $\downarrow$

Abundance of

Faecalibacterium,

Alistipes, and

Escherichia $\uparrow$

Chitosan

CHD patients

Prebiotic

oligosaccha-

rides

Human 2 g/day

6 months

(COS)
Abundance of

Bacteroides,

Megasphaera,

Roseburia, Prevotella, and Bifidobacterium $\downarrow$

Probiotic species

Lactobacillus,

Lactococcus, and

Phascolarctobacterium

HOMA-IR, homeostasis model assessment-estimated insulin resistance; HDL, high-density lipoprotein; LDL, low-density lipoprotein; TC/HDL-c ratio, total cholesterol to high-density lipoprotein cholesterol ratio; LDL-c/HDL-c ratio, low-density lipoprotein cholesterol to high-density lipoprotein cholesterol ratio; $\downarrow$, the levels, size or abundance decreased; $\uparrow$, the levels, size or abundance increased.

\subsection{Underlying Mechanisms of Prebiotics on CVD}

The mechanisms of action of prebiotics on host health have been proposed. First, prebiotics present in natural products or added into food could be fermented by gut bacteria 
and thus affect the structure of gut bacteria composition and the metabolic activity [130]. Second, prebiotics are able to change the environment in the gut, thereby reducing the $\mathrm{pH}$ and inhibiting the growth of pathogens in the colon [131]. The third mechanism is the beneficial effect on immunological function, though the evidence of this mechanism remains unclear. Several plausible explanations for the potential mechanisms of prebiotic beneficial effects on CVD have been proposed, which will be discussed and summarized in terms of two main aspects-modulation of gut microbiota and inflammatory responses [132].

(1) From the view of gut microbiota

Prebiotics improve human health by maintaining a balanced gut microbiota and restoring its homeostasis [133-135]. They are fermented mainly by saccharolytic bacteria and affect the composition of gut microbiota, especially favoring the growth of beneficial bacteria such as Lactobacillus and Bifidobacterium. These bacteria can also block the proliferation of harmful bacteria [133,134]. The beneficial effects of a prebiotic complex based on fermented wheat bran and prebiotic chitosan oligosaccharides on heart failure and CHD are partially attributed to the rebalancing of gut microbiota dysbiosis and promoting the growth of different probiotic species [126,129]. The metabolites of intestinal microbiota could be altered by prebiotics through the fermentation process. SCFAs including acetate, propionate, and butyrate are the main end-products of prebiotic fermentation by the gut bacteria. These metabolites show health-promoting functions, including lowering glycemic levels and body weight and improving intestinal membrane integrity [136]. SCFAs bind to deorphanized $G$ protein coupled receptors, such as free fatty acid receptors (FFAR) 2 and 3 and olfactory receptor 78 (Olfr78), which exhibit higher affinity for acetate and propionate, and GPR 109A, which has a higher affinity for butyrate [137-139]. Another function of SCFAs is to inhibit histone deacetylase. Histone deacetylase inhibitors (HDACs) can regulate chromatin structure to activate transcription factor and downstream gene expression [136]. SCFAs have been shown to be inversely associated with some risk factors for CVD. Acetate and propionate have been demonstrated to regulate blood pressure through Olfr78 and FFAR3, as seen in knockout animal models $[139,140]$. Butyrate attenuated blood pressure in angiotensin II-induced hypertensive rats, mainly via reducing the expression of renal protein receptors and renin [141]. Hyperglycemia in obesity and insulin resistance triggers increased gut permeability, which contributes to an inflammatory cascade [142]. SCFAs are crucial for maintaining a healthy gut, particularly in modulating epithelial integrity via tight junction proteins. For example, butyrate regulates proteins of the tight junction complex via acting on nucleotide-binding oligomerization domain-like receptors (NLRs), which subsequently modulate inflammation [143]. Additionally, SCFAs play a role in appetite regulation and energy intake to protect against obesity [144]. Glucose homeostasis can also be modulated by SCFA through improved insulin sensitivity via ameliorated gut barrier function and increased anti-inflammatory and antioxidant abilities [145].

Altogether, prebiotics, especially fibers or their end-product SCFAs in the gut, exhibit beneficial effects on CVD through several mechanisms involved in alteration of the gut environment, histone deacetylation, improvement of gut epithelial permeability contributing to reduced total and LDL cholesterol and hs-CRP, and lowering the incidence of CVD risk factors such as hypertension, obesity, and diabetes (Figure 2).

\section{(2) From the view of inflammatory response}

On the other hand, prebiotics play an important role in modulation of the immune response and host defenses $[133,134]$. Different types of prebiotics showed various immunological functions in innate and adaptive immune systems. Dendritic cells are the cell types most reported to be influenced by prebiotics. Three major forms of SCFAs, as the main metabolites from the prebiotics in the colon, exhibit different immunomodulatory effects. Expression of Foxp3 by dendritic cells can be induced by propionate, but not acetate, possibly due to the lack of HDAC activity [146]. Among SCFAs, butyrate is more effective than propionate and acetate in inducing immunomodulation. Moreover, it reduces the secretion of dendritic cell IL-12 and IL- 6 cytokine and promotes $\mathrm{T}_{\text {reg }}$ cells 
by dendritic cells [146]. Another study also confirmed that butyrate induced $\mathrm{T}_{\text {reg }}$ cells and IL-10-secreting T cells through binding to GPR109a on colonic dendritic cells and macrophages [138]. In the adaptive immune system, SCFAs also show beneficial effects on lymphocytes. The introduction of a mixture of 17 Clostridia strains ameliorated colitis and allergic diarrhea in mice due to production of SCFAs that bound to GPCR 43 and subsequently attenuated those diseases through a $\mathrm{T}_{\text {reg }} /$ TGF- $\beta$-dependent mechanism $[147,148]$. In addition, gut microbiota may influence brain activity and host physiological status through SCFAs, since these microbially derived products are involved in the signaling to the brain via nerve activation. Butyrate and propionate can regulate neurotransmission by increasing expression of tyrosine hydroxylase, which is important for dopamine and noradrenaline synthesis [149]. Evidence also suggests that propionate can lower levels of the indoleamine serotonin GABA as well as dopamine [150]. Thus, SCFAs could regulate the immune system through the gut-brain axis.

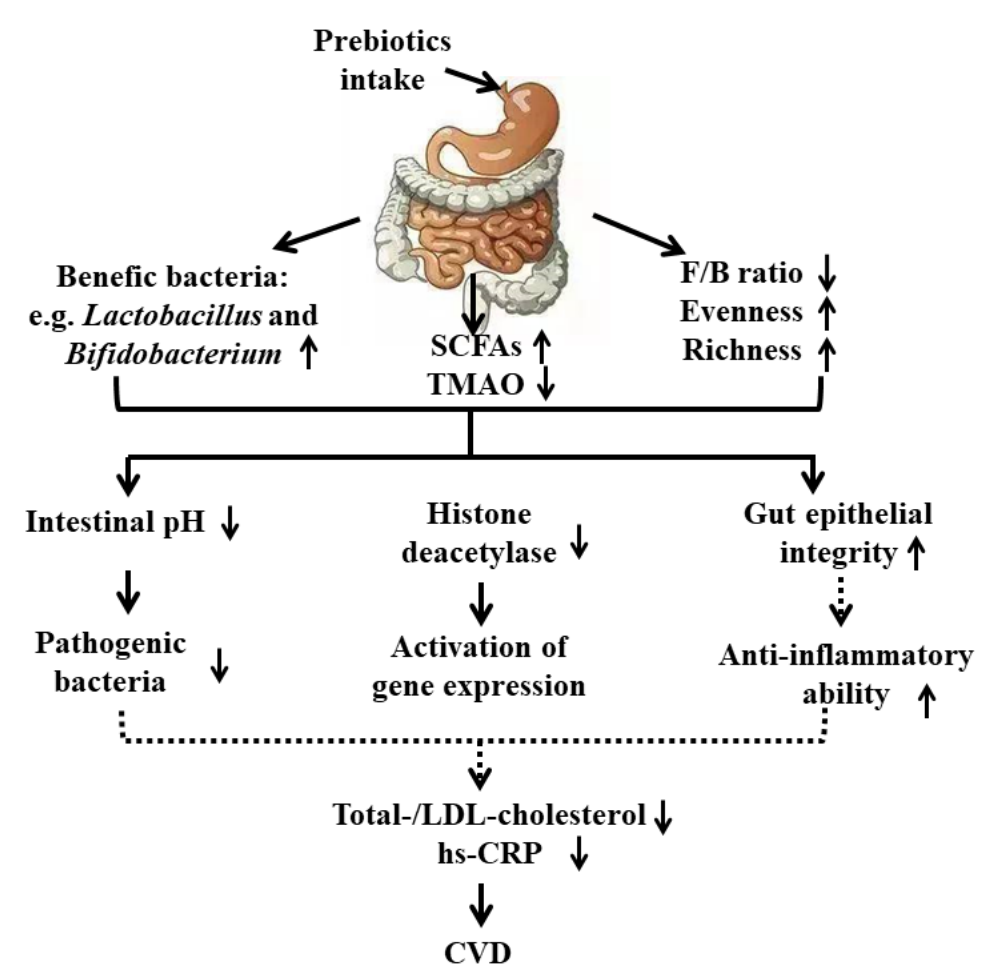

Figure 2. Mechanisms of the beneficial role of prebiotics on CVD. Solid line represents direct outcome. Dashed line represents indirect outcome. SCFAs, short chain fatty acids; LDL-cholesterol, low density lipid-cholesterol; hs-CRP, high sensitivity C-reactive protein.

Only a few articles have reported on the immunomodulatory function of prebiotics on CVD. Specific prebiotics, GOS, FOS, and pectin-derived acidic OS, exhibited an immunomodulatory effect during the early phase of a murine immune response in C57BL/ 6 mice [151]. Nutritional supplementation with prebiotics in elderly persons reduced the levels of pro-inflammatory factors, leading to an overall decrease in gut inflammation [152,153]. One abovementioned study also highlighted the potential role of prebiotics in CVD via improving proinflammatory cytokines [74]. Another study indicated that inulin treatment improved atherosclerosis and the number of macrophages in male APOE*3-Leiden mice [125]. The association between inflammation and cardiovascular risks has been supported by much research. Thus, prebiotics have a positive effect in preventing the development of CVD, partially through their anti-inflammatory action. 


\section{Beneficial Effects of Postbiotics on CVD}

Though the precise definition of postbiotics is under discussion, according to Tsilingiri et al., postbiotics include any substance released by or produced through the metabolic activity of the microorganism, which exerts beneficial effects on the host, directly or indirectly [154]. Postbiotics cannot be considered as synbiotics based on the current literature. The concept of postbiotics strengthens the beneficial effects of the microbiota through the secretion of various bioactive metabolites. Postbiotics, although not containing live bacteria, show benefits on host health via mechanisms similar to probiotics. In general, the currently available classes of postbiotic substances include (1) cell-free supernatants that have biologically active metabolites secreted by bacteria and yeast into the surrounding liquid; (2) exopolysaccharides produced by biopolymers, released from microorganisms; (3) antioxidant enzymes generated from microorganisms to protect against the harmful effects of ROS; (4) cell wall fragments, including bacterial lipoteichoic acid (LTA); (5) SCFAs, which are the products of plant polysaccharide breakdown by intestinal microbiota; (6) bacterial lysates obtained by the chemical or mechanical degradation of Gram-positive and Gram-negative bacteria; (7) metabolites produced by gut microbiota [155]. These postbiotics display many beneficial effects on the human body, such as immunomodulatory effects, antitumor effects, infection prevention, and accelerated wound healing. It is of interest that postbiotics have antiatherosclerotic effects. For example, Kefiran, an exopolysaccharide produced by Lactobacillus kefiranofaciens, prevented the onset and development of atherosclerosis in hypercholesterolemic rabbits, resulting in the reduction of inflammation and lipid concentration as well as the prevention of cholesterol accumulation in macrophages [156]. In addition, fragmented lactic acid bacterial cells from Lactobacillus amylovorus CP1563 might be beneficial for the prevention and treatment of dyslipidemia by attenuating the levels of LDL cholesterol and triglycerides while increasing the level of beneficial HDL cholesterol in an obese mouse model [157]. Although the potential mechanisms of postbiotic action on CVD have not been elucidated, it is intriguing to investigate the beneficial roles of postbiotics in this disease.

\section{Role of Probiotics and Prebiotics in Other CVD: Hypertension}

Hypertension is one of the most important risk factors of CVD. The therapeutic effects of probiotics, including probiotic strains and products fermented by live probiotics, on hypertension in both animal models and humans have been reported $[33,158,159]$. Orally administered pure strains, such as those belonging to L. plantarum, L. fermentum, L. coryniformis, L. gasseri, L. casei, B. longum, B. breve, and B. infantis, at optimal doses could alleviate high blood pressure in hypertensive patients and animals [160-163]. The antihypertensive effects of probiotics, especially lactic acid bacteria, contribute to an array of proteolytic cassettes and peptide transporters [164]. The most studied fermented milk products for their hypotensive effect are yogurt, cheese, and kefir, which contain live probiotic strains. For example, the consumption of fermented milk reduced systolic blood pressure, probably through milk-derived tripeptides isoleucine-proline-proline (Ile-Pro-Pro) and valine-proline-proline (Val-Pro-Pro), via inhibiting ACE in both hypertensive patients and spontaneously hypertensive rats (SHRs) $[165,166]$. Their antihypertensive mechanisms involve production of fermented food-derived bioactive peptides or polyphenols to further regulate RAAS, rebalance gut microbiota, and reduce inflammatory responses.

In addition, a growing body of evidence indicates that prebiotics, especially fiber and its end-product fermented by gut microbiota, were able to ameliorate hypertension. A diet high in fiber changed the gut microbiota and prevented the development of hypertension and heart failure in mice. The benefits of fiber might be due to the generation of one type of metabolite produced by gut microbiota: acetate. Acetate intake in this study effects several molecular changes associated with improved cardiovascular health and function [167]. The other two main SCFAs, propionate and butyrate, were also reported to improve hypertension and its associated cardiovascular damage [141,168-170]. The antihypertensive effects of these SCFAs might be through suppressing renal (pro) renin 
and the intrarenal renin-angiotensin system or inhibiting the COX2/PGE2 pathway via a HDAC5/HDAC6-dependent mechanism.

\section{Future Perspectives}

Abundant studies have been conducted to investigate the roles of probiotics and prebiotics in different diseases, including CVD. Despite being generally recognized as safe (GRAS) dietary supplements, with approval from the Food and Drug Administration (FDA) not required, the effects of probiotics and prebiotics on bloating, flatulence, and high osmotic pressure need to be further investigated [171]. In addition, specific dosages of probiotics and prebiotics should be considered to avoid potential adverse reactions. Although it is evident that consumption of probiotics and prebiotics is beneficial for CVD and promising as therapeutic strategies to manage conventional cardiovascular disease, contradictory findings are also reported in the literature, which are not presented in this review as we focused on CHD and stroke. There are still quite a few limitations in the use of probiotics, such as safety issues in vulnerable populations, limited studies evaluating the viability of live bacteria once in the intestine and the differences between viable or non-viable microorganisms, and lack of convincing evidence from clinical trials for certain indications. The recommendations from recent surveys on probiotic prescribing practices among health care providers and a review of current guidelines and published large clinical trials appear to be non-specific and inconsistent. Issues with the use of live microorganisms, especially the safety issues due to translocation of bacteria from the gut to the systemic circulation, lead to an increased interest in the use of postbiotics, which could be a safe and feasible strategy for the management of different diseases. However, the use of postbiotics in CVD is a relatively new area, and limited studies have been reported. In future, the number of investigations focusing on the health benefits of prebiotics and the possible mechanisms of action involved might be increased.

The introduction of probiotics and prebiotics could alleviate CVD via improving gut microbiota dysbiosis. Nevertheless, the interaction between supplemented probiotics and indigenous gut bacteria still needs to be clarified. Gut microbiome investigations are still complicated and far from standardized. In order to clearly elucidate the role of gut microbiota on CVD, sample sizes need to be adequate and proper control groups are required. Moreover, the positive effect of probiotics and prebiotics on CVD through anti-inflammatory modulation has been demonstrated, yet the underlying mechanisms remain largely unclear, and more evidence is needed.

\section{Conclusions}

In this review, we summarized the published results and proposed novel mechanisms that could contribute to the development of CVD, such as the metabolites produced from probiotics or prebiotics involved in immunomodulation via the gut-brain axis. Due to the limitations of probiotics and prebiotics, we also included a discussion of postbiotics, which is an intriguing field and a promising therapeutic strategy for the prevention of CVD in the future. CVD is undoubtedly linked to an increased risk of morbidity and mortality across the world. The intake of probiotics and prebiotics plays an important role in preventing and delaying the development of this disease. The levels of crucial CVD markers, namely LDL cholesterol and CRP, are significantly improved by the introduction of various probiotic strains and prebiotics. The underlying mechanisms of their protective effect in CVD, especially CHD and stroke, have been proposed. Furthermore, numerous studies suggest that probiotics and prebiotics protect against CVD by altering gut microbiota and intervening in inflammatory responses. These two categories of supplements could restore the normal gut microbiota, promote the growth of beneficial bacteria, and inhibit the proliferation of pathogens. Metabolites produced by gut microbiota, such as TMAO and SCFAs, could be modulated by pro- and prebiotics in patients having CVD. SCFAs, as the main microbial metabolites from prebiotics, are regarded as one of the major mediators in the communication between gut microbiota and the immune system, exhibit- 
ing immunomodulatory potential. To conclude, this review summarized the major findings from the literature to illustrate the potential underlying mechanisms of the beneficial effects of pro- and prebiotics, which could be considered as a promising intervention strategy to prevent or improve CVD via targeting the gut microbiota and maintaining immune homeostasis in the field (Figure 3).

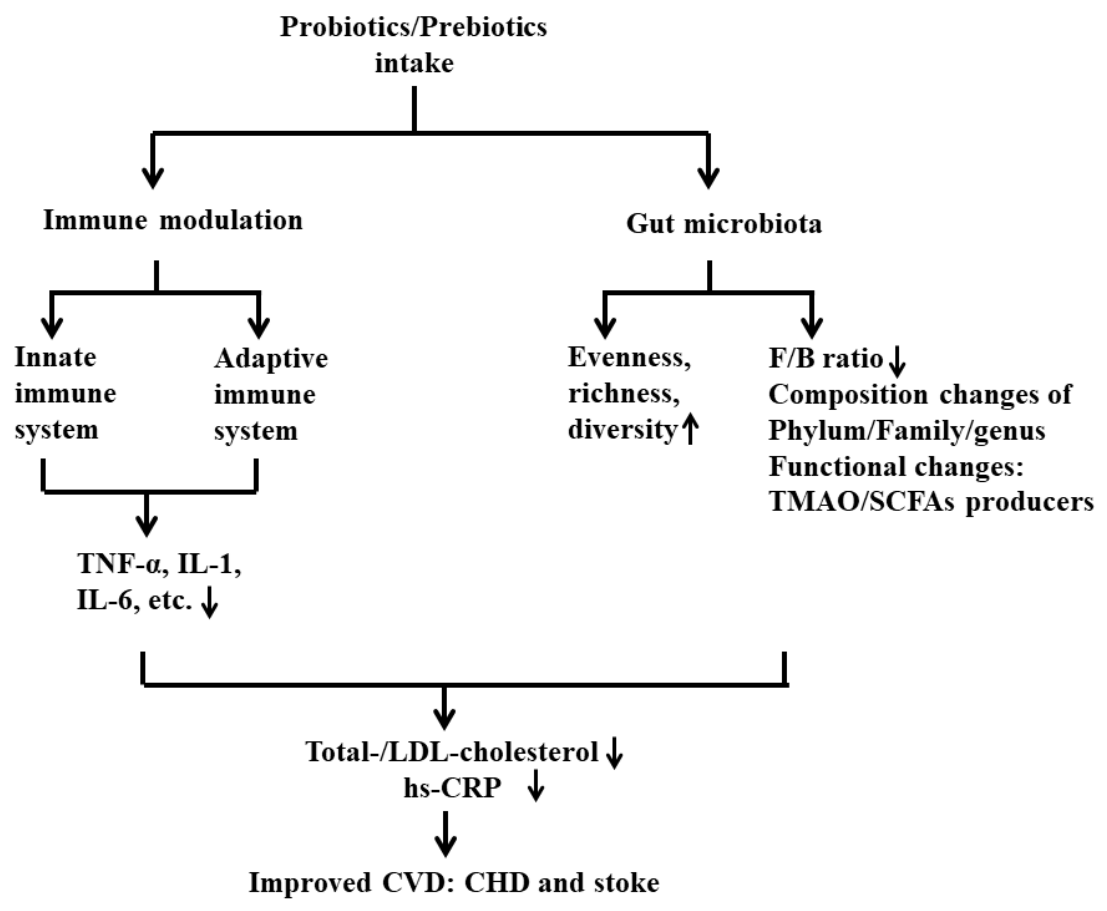

Figure 3. Summary of the mechanisms of the beneficial role of probiotics and prebiotics in CVD via gut microbiota and immune responses.

Author Contributions: Organizing and drafting the manuscript, H.W.; editing and supervision, J.C. All authors have read and agreed to the published version of the manuscript.

Funding: This research received no external funding.

Conflicts of Interest: The authors declare no conflict of interest.

\section{References}

1. World Health Organization. Global Atlas on Cardiovascular Disease Prevention and Control; World Health Organization in collaboration with the World Heart Federation and the World Stroke Organization; Regional Office for Europe: Copenhagen, Denmark, 2011.

2. Saxelby, C. Cardiovascular disease: Diet, nutrition and emerging risk factors. Nutr. Diet. 2006, 63, 189-191. [CrossRef]

3. Roger, V.L.; Go, A.S.; Lloyd-Jones, D.M.; Benjamin, E.J.; Berry, J.D.; Borden, W.B.; Bravata, D.M.; Dai, S.; Ford, E.S.; Fox, C.S.; et al. Heart disease and stroke statistics—2012 update: A report from the American Heart Association. Circulation 2010, $125,188$.

4. Hill, C.; Guarner, F.; Reid, G.; Gibson, G.R.; Merenstein, D.J.; Pot, B.; Morelli, L.; Canani, R.B.; Flint, H.J.; Salminen, S.; et al. Expert Consensus Document: The International Scientific Association for Probiotics and Prebiotics consensus statement on the scope and appropriate use of the term probiotic. Nat. Rev. Gastroenterol. Hepatol. 2014, 11, 506-514. [CrossRef]

5. Gibson, G.R.; Probert, H.M.; Loo, J.V.; Rastall, R.A.; Roberfroid, M.B. Dietary modulation of the human colonic microbiota: Updating the concept of prebiotics. Nutr. Res. Rev. 2004, 17, 259-275. [CrossRef]

6. Gibson, G.R.; Roberfroid, M.B. Dietary Modulation of the human colonic microbiota-introducing the concept of Prebiotics. J. Nutr. 1995, 125, 1401-1412. [CrossRef]

7. Cerdó, T.; García-Santos, J.A.; Bermúdez, M.G.; Campoy, C. The role of Probiotics and Prebiotics in the prevention and treatment of obesity. Nutrients 2019, 11, 635. [CrossRef]

8. Mishra, S.P.; Wang, S.; Nagpal, R.; Miller, B.; Singh, R.; Taraphder, S.; Yadav, H. Probiotics and Prebiotics for the amelioration of type 1 Diabetes: Present and future perspectives. Microorganism 2019, 7, 67. [CrossRef]

9. Oniszczuk, A.; Oniszczuk, T.; Gancarz, M.; Szymańska, J. Role of gut microbiota, Probiotics and Prebiotics in the cardiovascular diseases. Molecules 2021, 26, 1172. [CrossRef] 
10. Al Bander, Z.; Nitert, M.D.; Mousa, A.; Naderpoor, N. The gut microbiota and inflammation: An overview. Int. J. Environ. Res. Public Health 2020, 17, 7618. [CrossRef]

11. Guo, C.; Zhang, L. Cholesterol-lowering effects of probiotics-A review. Acta Microbiol. Sin. 2010, 50, 1590-1599.

12. Tringe, S.; von Mering, C.; Kobayashi, A.; Salamov, A.A.; Chen, K.; Chang, H.W.; Podar, M.; Short, J.M.; Mathur, E.J.; Detter, J.C.; et al. Comparative metagenomics of microbial communities. Science 2005, 308, 554-557. [CrossRef]

13. Tang, W.W.; Hazen, S.L. The contributory role of gut microbiota in cardiovascular disease. J. Clin. Investig. 2014, 124, 4204-4211. [CrossRef]

14. Kitai, T.; Tang, W.W. Gut microbiota in cardiovascular disease and heart failure. Clin. Sci. 2018, 132, 85-91. [CrossRef]

15. Lässiger-Herfurth, A.; Pontarollo, G.; Grill, A.; Reinhardt, C. The gut microbiota in cardiovascular disease and arterial thrombosis. Microorganism 2019, 7, 691. [CrossRef]

16. Li, D.Y.; Tang, W.H.W. Gut microbiota and atherosclerosis. Curr. Atheroscler. Rep. 2017, 19, 39. [CrossRef] [PubMed]

17. Pevsner-Fischer, M.; Blacher, E.; Tatirovsky, E.; Ben-Dov, I.; Elinav, E. The gut microbiome and hypertension. Curr. Opin. Nephrol. Hypertens. 2017, 26, 1-8. [CrossRef] [PubMed]

18. Frei, R.; Akdis, M.; O'Mahony, L. Prebiotics, probiotics, synbiotics, and the immune system. Curr. Opin. Gastroenterol. 2015, 31, 153-158. [CrossRef]

19. Golia, E.; Limongelli, G.; Natale, F.; Fimiani, F.; Maddaloni, V.; Pariggiano, I.; Bianchi, R.; Crisci, M.; D’Acierno, L.; Giordano, R.; et al. Inflammation and cardiovascular disease: From pathogenesis to therapeutic target. Curr. Atheroscler. Rep. 2014, 16, 1-7. [CrossRef]

20. Benjamin, E.J.; Blaha, M.J.; Chiuve, S.E.; Cushman, M.; Das, S.R.; Deo, R.; de Ferranti, S.D.; Floyd, J.; Fornage, M.; Gillespie, C.; et al. Heart disease and stroke statistics-2017 update: A report from the American heart association. Circulation 2017, 135, e146-e603. [CrossRef]

21. Frostegård, J. Immunity, atherosclerosis and cardiovascular disease. BMC Med. 2013, 11, 1-117. [CrossRef] [PubMed]

22. Asada, Y.; Yamashita, A.; Sato, Y.; Hatakeyama, K. Thrombus formation and propagation in the onset of cardiovascular events. J. Atheroscler. Thromb. 2018, 25, 653-664. [CrossRef] [PubMed]

23. Kurilenko, N.; Fatkhullina, A.; Mazitova, A.; Koltsova, E. Act locally, act globally-microbiota, barriers, and cytokines in atherosclerosis. Cells 2021, 10, 348. [CrossRef]

24. Paganelli, F.; Mottola, G.; Fromonot, J.; Marlinge, M.; Deharo, P.; Guieu, R.; Ruf, J. Hyperhomocysteinemia and cardiovascular disease: Is the adenosinergic system the missing link? Int. J. Mol. Sci. 2021, 22, 1690. [CrossRef]

25. Balakumar, P.; Maung-U, K.; Jagadeesh, G. Prevalence and prevention of cardiovascular disease and diabetes mellitus. Pharmacol. Res. 2016, 113, 600-609. [CrossRef]

26. Dolara, A. Medication adherence in cardiovascular diseases. Recenti Prog. Med. 2018, 109, 108-112. [CrossRef]

27. Aggarwal, M.; Bozkurt, B.; Panjrath, G.; Aggarwal, B.; Ostfeld, R.J.; Barnard, N.D.; Gaggin, H.; Freeman, A.M.; Allen, K.; Madan, S.; et al. Lifestyle modifications for preventing and treating heart failure. J. Am. Coll. Cardiol. 2018, 72, 2391-2405. [CrossRef]

28. Abrignani, M.G.; Area, Y.C.A.O.B.O.C.P.; Lucà, F.; Favilli, S.; Benvenuto, M.; Rao, C.M.; Di Fusco, S.A.; Gabrielli, D.; Gulizia, M.M. Lifestyles and cardiovascular prevention in childhood and adolescence. Pediatr. Cardiol. 2019, 40, 1113-1125. [CrossRef]

29. Aggarwal, M.; Aggarwal, B.; Rao, J. Integrative medicine for cardiovascular disease and prevention. Med Clin. N. Am. 2017, 101, 895-923. [CrossRef] [PubMed]

30. Asgary, S.; Rastqar, A.; Keshvari, M. Functional food and cardiovascular disease prevention and treatment: A review. J. Am. Coll. Nutr. 2018, 37, 429-455. [CrossRef]

31. Wang, Z.; Zhao, Y. Gut microbiota derived metabolites in cardiovascular health and disease. Protein Cell 2018, 9, 416-431. [CrossRef]

32. Ilatovskaya, D.V.; Halade, G.V.; DeLeon-Pennell, K.Y. Adaptive immunity-driven inflammation and cardiovascular disease. Am. J. Physiol. Circ. Physiol. 2019, 317, H1254-H1257. [CrossRef]

33. Sudha, R.; Upadrasta, A.; Madempudi, R.S. Probiotics and blood pressure: Current insights. Integr. Blood Press. Control. 2016, 9 , 33-42. [CrossRef]

34. Sekirov, I.; Russell, S.L.; Antunes, L.C.M.; Finlay, B.B. Gut Microbiota in health and disease. Physiol. Rev. 2010, 90, 859-904. [CrossRef]

35. Sender, R.; Fuchs, S.; Milo, R. Revised estimates for the number of human and bacteria cells in the body. PLoS Biol. 2016, 14, e1002533. [CrossRef]

36. Yang, X.; Xie, L.; Li, Y.; Wei, C. More than 9,000,000 Unique genes in human gut bacterial community: Estimating gene numbers inside a human body. PLoS ONE 2009, 4, e6074. [CrossRef] [PubMed]

37. Li, J.; Jia, H.; Cai, X.; Zhong, H.; Feng, Q.; Sunagawa, S.; Arumugam, M.; Kultima, J.R.; Prifti, E.; Nielsen, T.; et al. An integrated catalog of reference genes in the human gut microbiome. Nat. Biotechnol. 2014, 32, 834-841. [CrossRef]

38. Arora, T.; Bäckhed, F. The gut microbiota and metabolic disease: Current understanding and future perspectives. J. Intern. Med. 2016, 280, 339-349. [CrossRef] [PubMed]

39. DiBaise, J.K.; Frank, D.N.; Mathur, R. Impact of the gut microbiota on the development of obesity: Current concepts. Am. J. Gastroenterol. Suppl. 2012, 1, 22-27. [CrossRef]

40. Huang, L.; Thonusin, C.; Chattipakorn, N.; Chattipakorn, S.C. Impacts of gut microbiota on gestational diabetes mellitus: A comprehensive review. Eur. J. Nutr. 2021, 1-18. [CrossRef] 
41. Yang, T.; Santisteban, M.M.; Rodriguez, V.; Vermali, R.; Li, E.; Ahmari, N.; Carvajal, J.M.; Zadeh, M.; Gong, M.; Qi, Y.; et al. Gut dysbiosis is linked to hypertension. Hypertension 2015, 65, 1331-1340. [CrossRef]

42. Plovier, H.; Everard, A.; Druart, C.; Depommier, C.; Van Hul, M.; Geurts, L.; Chilloux, J.; Ottman, N.; Duparc, T.; Lichtenstein, L.; et al. A purified membrane protein from Akkermansia muciniphila or the pasteurized bacterium improves metabolism in obese and diabetic mice. Nat. Med. 2017, 23, 107-113. [CrossRef]

43. Allen, S.J.; Martinez, E.G.; Gregorio, G.V.; Dans, L.F. Probiotics for treating acute infectious diarrhoea. Cochrane Database Syst. Rev. 2010, 2010, CD003048. [CrossRef]

44. Macfarlane, S.; Macfarlane, G.T. Regulation of short-chain fatty acid production. Proc. Nutr. Soc. 2003, 62, 67-72. [CrossRef] [PubMed]

45. González-Regueiro, J.A.; Moreno-Castañeda, L.; Uribe, M.; Chávez-Tapia, N.C. The role of bile acids in glucose metabolism and their relation with diabetes. Ann. Hepatol. 2017, 16, S15-S20. [CrossRef]

46. Ascher, S.; Reinhardt, C. The gut microbiota: An emerging risk factor for cardiovascular and cerebrovascular disease. Eur. J. Immunol. 2018, 48, 564-575. [CrossRef] [PubMed]

47. Pasini, E.; Aquilani, R.; Testa, C.; Baiardi, P.; Angioletti, S.; Boschi, F.; Verri, M.; Dioguardi, F.S. Pathogenic gut flora in patients with chronic heart failure. JACC Hear. Fail. 2016, 4, 220-227. [CrossRef] [PubMed]

48. Jie, Z.; Xia, H.; Zhong, S.-L.; Feng, Q.; Li, S.; Liang, S.; Zhong, H.; Liu, Z.; Gao, Y.; Zhao, H.; et al. The gut microbiome in atherosclerotic cardiovascular disease. Nat. Commun. 2017, 8, 845. [CrossRef] [PubMed]

49. Cui, X.; Ye, L.; Li, J.; Jin, L.; Wang, W.; Li, S.; Bao, M.; Wu, S.; Li, L.; Geng, B.; et al. Metagenomic and metabolomic analyses unveil dysbiosis of gut microbiota in chronic heart failure patients. Sci. Rep. 2018, 8, 1-15. [CrossRef] [PubMed]

50. Randrianarisoa, E.; Lehn-Stefan, A.; Wang, X.; Hoene, M.; Peter, A.; Heinzmann, S.S.; Zhao, X.; Königsrainer, I.; Königsrainer, A.; Balletshofer, B.; et al. Relationship of serum trimethylamine N-Oxide (TMAO) levels with early Atherosclerosis in humans. Sci. Rep. 2016, 6, 26745. [CrossRef]

51. Gregory, J.C.; Buffa, J.A.; Org, E.; Wang, Z.; Levison, B.S.; Zhu, W.; Wagner, M.A.; Bennett, B.J.; Li, L.; Didonato, J.A. Transmission of Atherosclerosis susceptibility with gut microbial transplantation. J. Biol. Chem. 2015, 290, 5647-5660. [CrossRef]

52. Li, J.; Lin, S.; Vanhoutte, P.M.; Woo, C.W.H.; Xu, A. Akkermansia muciniphila protects against atherosclerosis by preventing metabolic endotoxemia-induced inflammation in Apoe - / - Mice. Circulation 2016, 133, 2434-2446. [CrossRef]

53. Lehr, H.-A.; Sagban, T.A.; Ihling, C.; Zähringer, U.; Hungerer, K.-D.; Blumrich, M.; Reifenberg, K.; Bhakdi, S. Immunopathogenesis of Atherosclerosis. Circulation 2001, 104, 914-920. [CrossRef] [PubMed]

54. McIntyre, C.W.; Harrison, L.E.; Eldehni, M.T.; Jefferies, H.J.; Szeto, C.C.; John, S.G.; Sigrist, M.K.; Burton, J.; Hothi, D.; Korsheed, S.; et al. Circulating endotoxemia: A novel factor in systemic inflammation and cardiovascular disease in chronic kidney disease. Clin. J. Am. Soc. Nephrol. 2010, 6, 133-141. [CrossRef] [PubMed]

55. Ridlon, J.M.; Kang, D.-J.; Hylemon, P.B. Bile salt biotransformations by human intestinal bacteria. J. Lipid Res. 2006, 47, $241-259$. [CrossRef] [PubMed]

56. Kothari, D.; Patel, S.; Kim, S.-K. Probiotic supplements might not be universally-effective and safe: A review. Biomed. Pharmacother. 2019, 111, 537-547. [CrossRef]

57. Pandey, K.R.; Naik, S.R.; Vakil, B.V. Probiotics, prebiotics and synbiotics-A review. J. Food Sci. Technol. 2015, 52, 7577-7587. [CrossRef] [PubMed]

58. Singh, V.P.; Sharma, J.; Babu, S.; Rizwanulla; Singla, A. Role of probiotics in health and disease: A review. J. Pak. Med. Assoc. 2013, 63, 253-257. [PubMed]

59. Abraham, B.P.; Quigley, E.M. Probiotics in Inflammatory Bowel disease. Gastroenterol. Clin. N. Am. 2017, 46, 769-782. [CrossRef] [PubMed]

60. Sekine, K.; Watanabe-Sekine, E.; Ohta, J.; Toida, T.; Tatsuki, T.; Kawashima, T.; Hashimoto, Y. Induction and activation of tumoricidal cells In Vivo and In Vitro by the Bacterial Cell Wall of Bifidobacterium infantis. Bifid- Microflora 1994, $13,65-77$. [CrossRef]

61. Paparo, L.; Nocerino, R.; Di Scala, C.; Della Gatta, G.; Di Costanzo, M.; Buono, A.; Bruno, C.; Berni Canani, R. Targeting Food Allergy with Probiotics. Adv. Exp. Med. Biol 2019, 1125, 57-68. [CrossRef]

62. Huang, R.; Ning, H.; Shen, M.; Li, J.; Zhang, J.; Chen, X. Probiotics for the treatment of atopic dermatitis in children: A systematic review and meta-analysis of randomized controlled trials. Front. Cell. Infect. Microbiol. 2017, 7, 392. [CrossRef] [PubMed]

63. Chang, C.-J.; Lin, T.-L.; Tsai, Y.-L.; Wu, T.-R.; Lai, W.-F.; Lu, C.-C.; Lai, H.-C. Next generation probiotics in disease amelioration. J. Food Drug Anal. 2019, 27, 615-622. [CrossRef]

64. Lukiw, W.J. Bacteroides fragilis Lipopolysaccharide and Inflammatory Signaling in Alzheimer's Disease. Front. Microbiol. 2016, 7, 1544. [CrossRef]

65. Miquel, S.; Martin, R.; Rossi, O.; Humaran, L.G.B.; Chatel, J.; Sokol, H.; Thomas, M.; Wells, J.; Langella, P. Faecalibacterium prausnitzii and human intestinal health. Curr. Opin. Microbiol. 2013, 16, 255-261. [CrossRef] [PubMed]

66. Goodrich, J.K.; Waters, J.L.; Poole, A.C.; Sutter, J.L.; Koren, O.; Blekhman, R.; Beaumont, M.; Van Treuren, W.; Knight, R.; Bell, J.T.; et al. Human genetics shape the gut microbiome. Cell 2014, 159, 789-799. [CrossRef]

67. Raygan, F.; Rezavandi, Z.; Bahmani, F.; Ostadmohammadi, V.; Mansournia, M.A.; Tajabadi-Ebrahimi, M.; Borzabadi, S.; Asemi, Z The effects of probiotic supplementation on metabolic status in type 2 diabetic patients with coronary heart disease. Diabetol. Metab. Syndr. 2018, 10, 1-7. [CrossRef] 
68. Raygan, F.; Ostadmohammadi, V.; Bahmani, F.; Asemi, Z. The effects of vitamin D and probiotic co-supplementation on mental health parameters and metabolic status in type 2 diabetic patients with coronary heart disease: A randomized, double-blind, placebo-controlled trial. Prog. Neuro-Psychopharmacol. Biol. Psychiatry 2018, 84, 50-55. [CrossRef]

69. Raygan, F.; Ostadmohammadi, V.; Asemi, Z. The effects of probiotic and selenium co-supplementation on mental health parameters and metabolic profiles in type 2 diabetic patients with coronary heart disease: A randomized, double-blind, placebocontrolled trial. Clin. Nutr. 2019, 38, 1594-1598. [CrossRef]

70. Farrokhian, A.; Raygan, F.; Soltani, A.; Tajabadi-Ebrahimi, M.; Esfahani, M.S.; Karami, A.A.; Asemi, Z. The effects of synbiotic supplementation on carotid intima-media thickness, biomarkers of inflammation, and oxidative stress in people with overweight, diabetes, and coronary heart disease: A randomized, double-blind, placebo-controlled trial. Probiotics Antimicrob. Proteins 2017, 11, 133-142. [CrossRef]

71. Tajabadi-Ebrahimi, M.; Sharifi, N.; Farrokhian, A.; Raygan, F.; Karamali, F.; Razzaghi, R.; Taheri, S.; Asemi, Z. A Randomized controlled clinical trial investigating the effect of synbiotic administration on markers of insulin metabolism and lipid profiles in overweight type 2 diabetic patients with coronary heart disease. Exp. Clin. Endocrinol. Diabetes 2016, 125, 21-27. [CrossRef]

72. Malik, M.; Suboc, T.M.; Tyagi, S.; Salzman, N.; Wang, J.; Ying, R.; Tanner, M.J.; Kakarla, M.; Baker, J.E.; Widlansky, M.E. Lactobacillus plantarum 299v supplementation improves vascular endothelial function and reduces inflammatory biomarkers in men with stable coronary artery disease. Circ. Res. 2018, 123, 1091-1102. [CrossRef] [PubMed]

73. Moludi, J.; Kafil, H.S.; Qaisar, S.A.; Gholizadeh, P.; Alizadeh, M.; Vayghyan, H.J. Effect of probiotic supplementation along with calorie restriction on metabolic endotoxemia, and inflammation markers in coronary artery disease patients: A double blind placebo controlled randomized clinical trial. Nutr. J. 2021, 20, 1-10. [CrossRef] [PubMed]

74. Moludi, J.; Khedmatgozar, H.; Nachvak, S.M.; Abdollahzad, H.; Moradinazar, M.; Tabaei, A.S. The effects of co-administration of probiotics and prebiotics on chronic inflammation, and depression symptoms in patients with coronary artery diseases: A randomized clinical trial. Nutr. Neurosci. 2021, 10,1-10. [CrossRef]

75. Sun, J.; Ling, Z.; Wang, F.; Chen, W.; Li, H.; Jin, J.; Zhang, H.; Pang, M.; Yu, J.; Liu, J. Clostridium butyricum pretreatment attenuates cerebral ischemia/reperfusion injury in mice via anti-oxidation and anti-apoptosis. Neurosci. Lett. 2016, 613, 30-35. [CrossRef]

76. Akhoundzadeh, K.; Vakili, A.; Shadnoush, M.; Sadeghzadeh, J. Effects of the oral ingestion of probiotics on brain damage in a transient model of focal cerebral ischemia in mice. Iran J. Med Sci. 2018, 43, 32-40.

77. Li, L.; Wang, M.; Chen, J.; Xu, Z.; Wang, S.; Xia, X.; Liu, D.; Wang, S.; Xie, C.; Wu, J.; et al. Preventive effects of bacillus licheniformis on heat stroke in rats by sustaining intestinal barrier function and modulating gut microbiota. Front. Microbiol. 2021, $12,630841$. [CrossRef]

78. Wanchao, S.; Chen, M.; Zhiguo, S.; Futang, X.; Mengmeng, S. Protective effect and mechanism of Lactobacillus on cerebral ischemia reperfusion injury in rats. Braz. J. Med Biol. Res. 2018, 51, 51. [CrossRef] [PubMed]

79. Sánchez, B.; Delgado, S.; Blanco-Míguez, A.; Lourenço, A.; Gueimonde, M.; Margolles, A. Probiotics, gut microbiota, and their influence on host health and disease. Mol. Nutr. Food Res. 2017, 61, 1600240. [CrossRef]

80. Wang, Z.; Klipfell, E.; Bennett, B.J.; Koeth, R.; Levison, B.S.; DuGar, B.; Feldstein, A.E.; Britt, E.B.; Fu, X.; Chung, Y.-M.; et al. Gut Flora metabolism of phosphatidylcholine promotes cardiovascular disease. Nature 2011, 472, 57-63. [CrossRef]

81. Korem, T.; Zeevi, D.; Suez, J.; Weinberger, A.; Avnit-Sagi, T.; Pompan-Lotan, M.; Matot, E.; Jona, G.; Harmelin, A.; Cohen, N.; et al. Growth dynamics of gut microbiota in health and disease inferred from single metagenomic samples. Science 2015, 349, 1101-1106. [CrossRef]

82. Vasquez, E.C.; Pereira, T.M.C.; Peotta, V.A.; Baldo, M.P.; Campos-Toimil, M. Probiotics as beneficial dietary supplements to prevent and treat cardiovascular diseases: Uncovering their impact on oxidative stress. Oxidative Med. Cell. Longev. 2019, 2019, 1-11. [CrossRef]

83. Brandsma, E.; Kloosterhuis, N.J.; Koster, M.; Dekker, D.C.; Gijbels, M.J.; van der Velden, S.; Ríos-Morales, M.; Van Faassen, M.J.; Loreti, M.G.; De Bruin, A.; et al. A proinflammatory gut microbiota increases systemic inflammation and accelerates atherosclerosis. Circ. Res. 2019, 124, 94-100. [CrossRef]

84. Karlsson, F.; Fåk, F.; Nookaew, I.; Tremaroli, V.; Fagerberg, B.; Petranovic, D.; Bäckhed, F.; Nielsen, J. Symptomatic atherosclerosis is associated with an altered gut metagenome. Nat. Commun. 2012, 3, 1245. [CrossRef]

85. Emoto, T.; Yamashita, T.; Sasaki, N.; Hirota, Y.; Hayashi, T.; So, A.; Kasahara, K.; Yodoi, K.; Matsumoto, T.; Mizoguchi, T.; et al. Analysis of gut microbiota in coronary artery disease patients: A possible link between gut microbiota and coronary artery disease. J. Atheroscler. Thromb. 2016, 23, 908-921. [CrossRef]

86. Emoto, T.; Yamashita, T.; Kobayashi, T.; Sasaki, N.; Hirota, Y.; Hayashi, T.; So, A.; Kasahara, K.; Yodoi, K.; Matsumoto, T.; et al. Characterization of gut microbiota profiles in coronary artery disease patients using data mining analysis of terminal restriction fragment length polymorphism: Gut microbiota could be a diagnostic marker of coronary artery disease. Hear. Vessel. 2016, 32, 39-46. [CrossRef]

87. Stanley, D.; Moore, R.J.; Wong, C.H.Y. An insight into intestinal mucosal microbiota disruption after stroke. Sci. Rep. 2018, 8, 1-12. [CrossRef] [PubMed]

88. Singh, V.; Roth, S.; Llovera, G.; Sadler, R.; Garzetti, D.; Stecher, B.; Dichgans, M.; Liesz, A. Microbiota dysbiosis controls the neuroinflammatory response after stroke. J. Neurosci. 2016, 36, 7428-7440. [CrossRef] 
89. Yamashiro, K.; Tanaka, R.; Urabe, T.; Ueno, Y.; Yamashiro, Y.; Nomoto, K.; Takahashi, T.; Tsuji, H.; Asahara, T.; Hattori, N. Gut dysbiosis is associated with metabolism and systemic inflammation in patients with ischemic stroke. PLOS ONE 2017, 12, e0171521. [CrossRef]

90. O'Morain, V.L.; Ramji, D.P. The potential of Probiotics in the prevention and treatment of Atherosclerosis. Mol. Nutr. Food Res. 2019, 64, e1900797. [CrossRef]

91. Jiang, T.; Wu, H.; Yang, X.; Li, Y.; Zhang, Z.; Chen, F.; Zhao, L.; Zhang, C. Lactobacillus Mucosae strain promoted by a high-fiber diet in genetic obese child alleviates lipid metabolism and modifies gut microbiota in $\mathrm{ApoE}^{-/-}$mice on a western diet. Microorganism 2020, 8, 1225. [CrossRef]

92. Hassan, A.; Din, A.U.; Zhu, Y.; Zhang, K.; Li, T.; Wang, Y.; Xu, S.; Lei, H.; Yu, X.; Wang, G. Anti-atherosclerotic effects of Lactobacillus plantarum ATCC 14917 in ApoE-/ - mice through modulation of proinflammatory cytokines and oxidative stress. Appl. Microbiol. Biotechnol. 2020, 104, 6337-6350. [CrossRef]

93. London, L.E.; Kumar, A.; Wall, R.; Casey, P.G.; O'Sullivan, O.; Shanahan, F.; Hill, C.; Cotter, P.; Fitzgerald, G.F.; Ross, R.; et al. Exopolysaccharide-producing probiotic lactobacilli reduce serum cholesterol and modify enteric microbiota in apoe-deficient mice. J. Nutr. 2014, 144, 1956-1962. [CrossRef]

94. Chan, Y.K.; El-Nezami, H.; Chen, Y.; Kinnunen, K.; Kirjavainen, P.V. Probiotic mixture VSL\#3 reduce high fat diet induced vascular inflammation and atherosclerosis in ApoE-/- mice. AMB Express 2016, 6, 61. [CrossRef]

95. Koeth, R.A.; Wang, Z.; Levison, B.S.; Buffa, J.A.; Org, E.; Sheehy, B.T.; Britt, E.B.; Fu, X.; Wu, Y.; Li, L.; et al. Intestinal microbiota metabolism of 1-carnitine, a nutrient in red meat, promotes atherosclerosis. Nat. Med. 2013, 19, 576-585. [CrossRef]

96. Wang, Z.; Roberts, A.; Buffa, J.A.; Levison, B.; Zhu, W.; Org, E.; Gu, X.; Huang, Y.; Zamanian-Daryoush, M.; Culley, M.K.; et al. Non-lethal inhibition of gut microbial trimethylamine production for the treatment of Atherosclerosis. Cell 2015, 163, 1585-1595. [CrossRef]

97. Craciun, S.; Balskus, E.P. Microbial conversion of choline to trimethylamine requires a glycyl radical enzyme. Proc. Natl. Acad. Sci. USA 2012, 109, 21307-21312. [CrossRef] [PubMed]

98. Koeth, R.A.; Levison, B.; Culley, M.K.; Buffa, J.A.; Wang, Z.; Gregory, J.C.; Org, E.; Wu, Y.; Li, L.; Smith, J.D.; et al. $\gamma$-Butyrobetaine Is a proatherogenic intermediate in gut microbial metabolism of L-Carnitine to TMAO. Cell Metab. 2014, 20, 799-812. [CrossRef]

99. Din, A.U.; Hassan, A.; Zhu, Y.; Yin, T.; Gregersen, H.; Wang, G. Amelioration of TMAO through probiotics and its potential role in atherosclerosis. Appl. Microbiol. Biotechnol. 2019, 103, 9217-9228. [CrossRef]

100. Qiu, L.; Tao, X.; Xiong, H.; Yu, J.; Wei, H. Lactobacillus plantarumZDY04 exhibits a strain-specific property of lowering TMAOviathe modulation of gut microbiota in mice. Food Funct. 2018, 9, 4299-4309. [CrossRef]

101. Veiga, P.; Pons, N.; Agrawal, A.; Oozeer, R.; Guyonnet, D.; Brazeilles, R.; Faurie, J.M.; van Hylckama Vlieg, J.E.; Houghton, L.A.; Whorwell, P.J.; et al. Changes of the human gut microbiome induced by a fermented milk product. Sci. Rep. 2014, 4, 6328. [CrossRef]

102. Prete, R.; Long, S.L.; Gallardo, A.L.; Gahan, C.G.; Corsetti, A.; Joyce, S.A. Beneficial bile acid metabolism from Lactobacillus plantarum of food origin. Sci. Rep. 2020, 10, 1-11. [CrossRef]

103. Li, H.; Sun, K.; Zhao, R.; Hu, J.; Hao, Z.; Wang, F.; Lu, Y.; Liu, F.; Zhang, Y. Inflammatory biomarkers of coronary heart disease. Front. Biosci. Schol. Ed. 2018, 10, 185-196. [CrossRef]

104. Galdeano, C.M.; Cazorla, S.I.; Dumit, J.M.L.; Vélez, E.; Perdigón, G. Beneficial Effects of Probiotic Consumption on the Immune System. Ann. Nutr. Metab. 2019, 74, 115-124. [CrossRef]

105. Galdeano, C.M.; Perdigon, G. Role of viability of probiotic strains in their persistence in the gut and in mucosal immune stimulation. J. Appl. Microbiol. 2004, 97, 673-681. [CrossRef] [PubMed]

106. Leblanc, A.D.M.D.; A Dogi, C.; Galdeano, C.M.; Carmuega, E.; Weill, R.; Perdigon, G. Effect of the administration of a fermented milk containing Lactobacillus casei DN-114001 on intestinal microbiota and gut associated immune cells of nursing mice and after weaning until immune maturity. BMC Immunol. 2008, 9, 27. [CrossRef]

107. Otte, J.-M.; Podolsky, D.K. Functional modulation of enterocytes by gram-positive and gram-negative microorganisms. Am. J. Physiol. Liver Physiol. 2004, 286, G613-G626. [CrossRef]

108. Cazorla, S.I.; Maldonado-Galdeano, C.; Weill, R.; De Paula, J.; Perdigón, G.D.V. Oral Administration of Probiotics Increases Paneth Cells and Intestinal Antimicrobial Activity. Front. Microbiol. 2018, 9, 736. [CrossRef]

109. Resta-Lenert, S.; Barrett, K.E. Live probiotics protect intestinal epithelial cells from the effects of infection with enteroinvasive Escherichia coli (EIEC). Gut 2003, 52, 988-997. [CrossRef] [PubMed]

110. Dai, C.; Zhao, D.H.; Jiang, M. VSL\#3 probiotics regulate the intestinal epithelial barrier in vivo and in vitro via the p38 and ERK signaling pathways. Int. J. Mol. Med. 2012, 29, 202-208. [CrossRef]

111. Li, J.; Sung, C.Y.; Lee, N.; Ni, Y.; Pihlajamäki, J.; Panagiotou, G.; El-Nezami, H. Probiotics modulated gut microbiota suppresses hepatocellular carcinoma growth in mice. Proc. Natl. Acad. Sci. USA 2016, 113, E1306-E1315. [CrossRef] [PubMed]

112. Camara-Lemarroy, C.R.; Ibarra-Yruegas, B.E.; Gongora-Rivera, F. Gastrointestinal complications after ischemic stroke. J. Neurol. Sci. 2014, 346, 20-25. [CrossRef] [PubMed]

113. Amiya, E.; Watanabe, M.; Komuro, I. The relationship between vascular function and the autonomic nervous system. Ann. Vasc. Dis. 2014, 7, 109-119. [CrossRef]

114. Strandwitz, P. Neurotransmitter modulation by the gut microbiota. Brain Res. 2018, 1693, 128-133. [CrossRef] [PubMed] 
115. Barrett, E.; Ross, R.P.; O'Toole, P.W.; Fitzgerald, G.F.; Stanton, C. $\gamma$-Aminobutyric acid production by culturable bacteria from the human intestine. J. Appl. Microbiol. 2012, 113, 411-417. [CrossRef] [PubMed]

116. Wang, Y. Prebiotics: Present and future in food science and technology. Food Res. Int. 2009, 42, 8-12. [CrossRef]

117. Markowiak, P.; Śliżewska, K. Effects of Probiotics, Prebiotics, and Synbiotics on human health. Nutrients 2017, 9, 1021. [CrossRef]

118. Ouwehand, A.C.; Derrien, M.; de Vos, W.; Tiihonen, K.; Rautonen, N. Prebiotics and other microbial substrates for gut functionality. Curr. Opin. Biotechnol. 2005, 16, 212-217. [CrossRef]

119. Slavin, J.L. Position of the American Dietetic Association: Health implications of dietary fiber. J. Am. Diet. Assoc. 2008, 108, 1716-1731. [CrossRef] [PubMed]

120. Tucker L.A; Thomas, K.S. Increasing total fiber intake reduces risk of weight and fat gains in women. J. Nutr. 2009, 139, 576-581. [CrossRef] [PubMed]

121. Hijová, E.; Szabadosova, V.; Štofilová, J.; Hrčková, G. Chemopreventive and metabolic effects of inulin on colon cancer development. J. Vet. Sci. 2013, 14, 387-393. [CrossRef]

122. Lai, S.; Mazzaferro, S.; Muscaritoli, M.; Mastroluca, D.; Testorio, M.; Perrotta, A.; Esposito, Y.; Carta, M.; Campagna, L.; Di Grado, M.; et al. Prebiotic therapy with inulin associated with low protein diet in chronic kidney disease patients: Evaluation of nutritional, cardiovascular and psychocognitive parameters. Toxins 2020, 12, 381. [CrossRef]

123. Aliasgharzadeh, A.; Khalili, M.; Mirtaheri, E.; Gargari, B.P.; Tavakoli, F.; Farhangi, M.A.; Babaei, H.; Dehghan, P. A combination of Prebiotic inulin and oligofructose improve some of cardiovascular disease risk factors in women with type 2 Diabetes: A randomized controlled clinical trial. Adv. Pharm. Bull. 2015, 5, 507-514. [CrossRef] [PubMed]

124. Queenan, K.M.; Stewart, M.L.; Smith, K.N.; Thomas, W.; Fulcher, R.G.; Slavin, J.L. Concentrated oat $\beta$-glucan, a fermentable fiber, lowers serum cholesterol in hypercholesterolemic adults in a randomized controlled trial. Nutr. J. 2007, 6, 6-8. [CrossRef] [PubMed]

125. Hoving, L.R.; De Vries, M.R.; De Jong, R.C.M.; Katiraei, S.; Pronk, A.; Quax, P.H.A.; Van Harmelen, V.; Van Dijk, K.W. The prebiotic inulin aggravates accelerated atherosclerosis in hypercholesterolemic APOE*3-leiden mice. Nutrients 2018, 10, 172. [CrossRef] [PubMed]

126. Vlasov, A.A.; Shperling, M.I.; Terkin, D.A.; Bystrova, O.V.; Osipov, G.A.; Salikova, S.P.; Grinevich, V.B. Effect of prebiotic complex on gut microbiota and endotoxemia in female rats with modeled heart failure. Bull. Exp. Biol. Med. 2020, 168, 435-438. [CrossRef] [PubMed]

127. Tai, E.S.; Fok, A.C.; Chu, R.; E Tan, C. A study to assess the effect of dietary supplementation with soluble fibre (Minolest) on lipid levels in normal subjects with hypercholesterolaemia. Ann. Acad. Med. Singap. 1999, 28, 209-213. [PubMed]

128. Lim, S.-H. Larch arabinogalactan attenuates myocardial injury by inhibiting apoptotic cascades in a rat model of ischemiareperfusion. J. Med. Food 2017, 20, 691-699. [CrossRef]

129. Jiang, T.; Xing, X.; Zhang, L.; Liu, Z.; Zhao, J.; Liu, X. Chitosan oligosaccharides show protective effects in coronary heart disease by improving antioxidant capacity via the increase in intestinal probiotics. Oxidative Med. Cell. Longev. 2019, $2019,1-11$. [CrossRef]

130. Van Loo, J.; Clune, Y.; Bennett, M.; Collins, J.K. The SYNCAN project: Goals, set-up, first results and settings of the human intervention study. Br. J. Nutr. 2005, 93, S91-S98. [CrossRef]

131. Gibson, G.; Wang, X. Regulatory effects of bifidobacteria on the growth of other colonic bacteria. J. Appl. Bacteriol. 1994, 77, 412-420. [CrossRef]

132. Schley, P.; Field, C.J. The immune-enhancing effects of dietary fibres and prebiotics. Br. J. Nutr. 2002, 87, 221-230. [CrossRef] [PubMed]

133. Farias, D.D.P.; de Araújo, F.F.; Neri-Numa, I.A.; Pastore, G.M. Prebiotics: Trends in food, health and technological applications. Trends Food Sci. Technol. 2019, 93, 23-35. [CrossRef]

134. Mohanty, D.; Misra, S.; Mohapatra, S.; Sahu, P.S. Prebiotics and synbiotics: Recent concepts in nutrition. Food Biosci. 2018, 26, 152-160. [CrossRef]

135. Quigley, E.M. Prebiotics and probiotics in digestive health. Clin. Gastroenterol. Hepatol. 2019, 17, 333-344. [CrossRef] [PubMed]

136. Tan, J.; McKenzie, C.; Potamitis, M.; Thorburn, A.N.; Mackay, C.R.; Macia, L. The role of short-chain fatty acids in health and disease. Adv. Immunol. 2014, 121, 91-119. [CrossRef]

137. Bolognini, D.; Tobin, A.B.; Milligan, G.; Moss, C.E. The pharmacology and function of receptors for short-chain fatty acids. Mol. Pharmacol. 2016, 89, 388-398. [CrossRef]

138. Singh, N.; Gurav, A.; Sivaprakasam, S.; Brady, E.; Padia, R.; Shi, H.; Thangaraju, M.; Prasad, P.D.; Manicassamy, S.; Munn, D.H.; et al. Activation of Gpr109a, Receptor for niacin and the commensal metabolite butyrate, suppresses colonic inflammation and carcinogenesis. Immunity 2014, 40, 128-139. [CrossRef]

139. Pluznick, J.L.; Protzko, R.J.; Gevorgyan, H.; Peterlin, Z.; Sipos, A.; Han, J.; Brunet, I.; Wan, L.-X.; Rey, F.; Wang, T.; et al. Olfactory receptor responding to gut microbiota-derived signals plays a role in renin secretion and blood pressure regulation. Proc. Natl. Acad. Sci. USA 2013, 110, 4410-4415. [CrossRef]

140. Natarajan, N.; Hori, D.; Flavahan, S.; Steppan, J.; Flavahan, N.A.; Berkowitz, D.E.; Pluznick, J.L. Microbial short chain fatty acid metabolites lower blood pressure via endothelial G protein-coupled receptor 41. Physiol. Genom. 2016, 48, 826-834. [CrossRef] 
141. Wang, L.; Zhu, Q.; Lu, A.; Liu, X.; Zhang, L.; Xu, C.; Liu, X.; Li, H.; Yang, T. Sodium butyrate suppresses angiotensin II-induced hypertension by inhibition of renal (pro)renin receptor and intrarenal renin-angiotensin system. J. Hypertens. 2017, 35, 1899-1908. [CrossRef]

142. Thaiss, C.A.; Levy, M.; Grosheva, I.; Zheng, D.; Soffer, E.; Blacher, E.; Braverman, S.; Tengeler, A.C.; Barak, O.; Elazar, M.; et al. Hyperglycemia drives intestinal barrier dysfunction and risk for enteric infection. Science 2018, 359, 1376-1383. [CrossRef] [PubMed]

143. Cheng, D.; Xu, J.-H.; Li, J.-Y.; Wang, S.-Y.; Wu, T.-F.; Chen, Q.-K.; Yu, T. Butyrate ameliorated-NLRC3 protects the intestinal barrier in a GPR43-dependent manner. Exp. Cell Res. 2018, 368, 101-110. [CrossRef]

144. Li, Z.; Yi, C.-X.; Katiraei, S.; Kooijman, S.; Zhou, E.; Chung, C.K.; Gao, Y.; van den Heuvel, J.K.; Meijer, O.C.; Berbée, J.F.P.; et al. Butyrate reduces appetite and activates brown adipose tissue via the gut-brain neural circuit. Gut 2018, 67, 1269-1279. [CrossRef] [PubMed]

145. Kim, Y.A.; Keogh, J.; Clifton, P.M. Probiotics, prebiotics, synbiotics and insulin sensitivity. Nutr. Res. Rev. 2018, 31, 35-51. [CrossRef] [PubMed]

146. Arpaia, N.; Campbell, C.; Fan, X.; Dikiy, S.; Van Der Veeken, J.; DeRoos, P.; Liu, H.; Cross, J.R.; Pfeffer, K.; Coffer, P.J.; et al. Metabolites produced by commensal bacteria promote peripheral regulatory T-cell generation. Nature 2013, 504, 451-455. [CrossRef] [PubMed]

147. Arpaia, N.; Rudensky, A.Y. Microbial metabolites control gut inflammatory responses: Figure 1. Proc. Natl. Acad. Sci. USA 2014, 111, 2058-2059. [CrossRef]

148. Atarashi, K.; Tanoue, T.; Oshima, K.; Suda, W.; Nagano, Y.; Nishikawa, H.; Fukuda, S.; Saito, T.; Narushima, S.; Hase, K.; et al. Treg induction by a rationally selected mixture of Clostridia strains from the human microbiota. Nature 2013, 500, 232-236. [CrossRef]

149. Ankova, B.B.; Agarwal, R.; Macfabe, D.F.; La Gamma, E.F. Enteric bacterial metabolites propionic and butyric acid modulate gene expression, including CREB-dependent catecholaminergic neurotransmission, in PC12 Cells-possible relevance to autism spectrum disorders. PLoS ONE 2014, 9, e103740. [CrossRef]

150. El-Ansary, A.K.; Ben Bacha, A.; Kotb, M. Etiology of autistic features: The persisting neurotoxic effects of propionic acid. J. Neuroinflammation 2012, 9, 74. [CrossRef]

151. Vos, A.P.; Knol, J.; Stahl, B.; M'Rabet, L.; Garssen, J. Specific prebiotic oligosaccharides modulate the early phase of a murine vaccination response. Int. Immunopharmacol. 2010, 10, 619-625. [CrossRef]

152. Schiffrin, E.J.; Thomas, D.R.; Kumar, V.B.; Brown, C.; Hager, C.; Van't Hof, M.A.; Morley, J.E.; Guigoz, Y. Systemic inflammatory markers in older persons: The effect of oral nutritional supplementation with prebiotics. J. Nutr. Health Aging 2007, 11, 475-479. [PubMed]

153. Vulevic, J.; Drakoularakou, A.; Yaqoob, P.; Tzortzis, G.; Gibson, G.R. Modulation of the fecal microflora profile and immune function by a novel trans-galactooligosaccharide mixture (B-GOS) in healthy elderly volunteers. Am. J. Clin. Nutr. 2008, 88, 1438-1446. [CrossRef] [PubMed]

154. Tsilingiri, K.; Rescigno, M. Postbiotics: What else? Benef. Microbes 2013, 4, 101-107. [CrossRef]

155. Żółkiewicz, J.; Marzec, A.; Ruszczyński, M.; Feleszko, W. Postbiotics-a step beyond pre- and probiotics. Nutrients 2020, $12,2189$. [CrossRef]

156. Uchida, M.; Ishii, I.; Inoue, C.; Akisato, Y.; Watanabe, K.; Hosoyama, S.; Toida, T.; Ariyoshi, N.; Kitada, M. Kefiran reduces atherosclerosis in rabbits fed a high cholesterol diet. J. Atheroscler. Thromb. 2010, 17, 980-988. [CrossRef] [PubMed]

157. Nakamura, F.; Ishida, Y.; Sawada, D.; Ashida, N.; Sugawara, T.; Sakai, M.; Goto, T.; Kawada, T.; Fujiwara, S. Fragmented lactic acid bacterial cells activate peroxisome proliferator-activated receptors and ameliorate dyslipidemia in obese mice. J. Agric. Food Chem. 2016, 64, 2549-2559. [CrossRef]

158. Thushara, R.M.; Gangadaran, S.; Solati, Z.; Moghadasian, M.H. Cardiovascular benefits of probiotics: A review of experimental and clinical studies. Food Funct. 2016, 7, 632-642. [CrossRef]

159. Daliri, E.B.-M.; Lee, B.H.; Oh, D.H. Current perspectives on antihypertensive probiotics. Probiotics Antimicrob. Proteins 2016, 9 , 91-101. [CrossRef]

160. Gómez-Guzmán, M.; Toral, M.; Romero, M.; Jimenez, R.; Galindo, P.; Sánchez, M.; Zarzuelo, M.J.; Olivares, M.; Galvez, J.; Duarte, J. Antihypertensive effects of probioticsLactobacillusstrains in spontaneously hypertensive rats. Mol. Nutr. Food Res. 2015, 59, 2326-2336. [CrossRef]

161. Sawada, H.; Furushiro, M.; Hirai, K.; Motoike, M.; Watanabe, T.; Yokokura, T. Purification and characterization of an antihypertensive compound from Lactobacillus casei. Agric. Biol. Chem. 1990, 54, 3211-3219. [CrossRef]

162. Rashid, S.K.; Idris-Khodja, N.; Auger, C.; Alhosin, M.; Boehm, N.; Oswald-Mammosser, M.; Schini-Kerth, V.B. Probiotics (VSL\#3) prevent endothelial dysfunction in rats with portal hypertension: Role of the angiotensin system. PLoS ONE 2014, 9, e97458. [CrossRef]

163. Vera, I.R.; Toral, M.; de la Visitación, N.; Sánchez, M.; Romero, M.; Olivares, M.; Jimenez, R.; Duarte, J. The probiotic lactobacillus fermentum prevents dysbiosis and vascular oxidative stress in rats with hypertension induced by chronic nitric oxide blockade. Mol. Nutr. Food Res. 2018, 62, e1800298. [CrossRef] [PubMed]

164. Liu, M.; Bayjanov, J.R.; Renckens, B.; Nauta, A.; Siezen, R.J. The proteolytic system of lactic acid bacteria revisited: A genomic comparison. BMC Genom. 2010, 11, 36. [CrossRef] [PubMed] 
165. Xu, J.-Y.; Qin, L.-Q.; Wang, P.-Y.; Li, W.; Chang, C. Effect of milk tripeptides on blood pressure: A meta-analysis of randomized controlled trials. Nutrition 2008, 24, 933-940. [CrossRef]

166. Nakamura, Y.; Yamamoto, N.; Sakai, K.; Takano, T. Antihypertensive effect of sour milk and peptides isolated from it that are inhibitors to angiotensin I-converting enzyme. J. Dairy Sci. 1995, 78, 1253-1257. [CrossRef]

167. Marques, F.Z.; Nelson, E.; Chu, P.-Y.; Horlock, D.; Fiedler, A.; Ziemann, M.; Tan, J.K.; Kuruppu, S.; Rajapakse, N.W.; El-Osta, A.; et al. High-fiber diet and acetate supplementation change the gut microbiota and prevent the development of hypertension and heart failure in hypertensive mice. Circulation 2017, 135, 964-977. [CrossRef] [PubMed]

168. Bartolomaeus, H.; Balogh, A.; Yakoub, M.; Homann, S.; Markó, L.; Höges, S.; Tsvetkov, D.; Krannich, A.; Wundersitz, S.; Avery, E.G.; et al. Short-chain fatty acid propionate protects from hypertensive cardiovascular damage. Circulation 2019, 139, 1407-1421. [CrossRef]

169. Juanola, O.; Ferrusquía-Acosta, J.; García-Villalba, R.; Zapater, P.; Magaz, M.; Marín, A.; Olivas, P.; Baiges, A.; Bellot, P.; Turon, F.; et al. Circulating levels of butyrate are inversely related to portal hypertension, endotoxemia, and systemic inflammation in patients with cirrhosis. FASEB J. 2019, 33, 11595-11605. [CrossRef]

170. Zhang, L.; Deng, M.; Lu, A.; Chen, Y.; Chen, Y.; Wu, C.; Tan, Z.; Boini, K.M.; Yang, T.; Zhu, Q.; et al. Sodium butyrate attenuates angiotensin II-induced cardiac hypertrophy by inhibiting COX2/PGE2 pathway via a HDAC5/HDAC6-dependent mechanism. J. Cell. Mol. Med. 2019, 23, 8139-8150. [CrossRef]

171. Williams, C.M. Effects of inulin on lipid parameters in humans. J. Nutr. 1999, 129, 1471s-1473s. [CrossRef] 